\title{
High bleeding risk and clinical outcomes in East Asian patients undergoing percutaneous coronary intervention: the PENDULUM registry
}

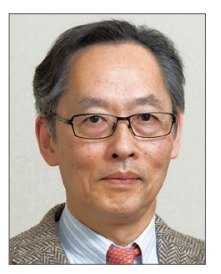

Masato Nakamura ${ }^{1 *}, \mathrm{MD}, \mathrm{PhD}$; Kazushige Kadota², MD, PhD; Koichi Nakao³, MD, PhD; Yoshihisa Nakagawa ${ }^{4}, \mathrm{MD}, \mathrm{PhD}$; Junya Shite ${ }^{5}, \mathrm{MD}, \mathrm{PhD}$; Hiroyoshi Yokoi ${ }^{6}, \mathrm{MD}, \mathrm{PhD}$; Ken Kozuma $^{7}$, MD, PhD; Kengo Tanabe ${ }^{8}$, MD, PhD; Raisuke Iijima ${ }^{1}, \mathrm{MD}, \mathrm{PhD}$; Atsushi Harada ${ }^{9}$, BPharm; Takeshi Kuroda ${ }^{9}, \mathrm{PhD}$; Yoshitaka Murakami ${ }^{10}, \mathrm{PhD}$

1. Division of Cardiovascular Medicine, Toho University Ohashi Medical Center, Tokyo, Japan; 2. Department of Cardiology, Kurashiki Central Hospital, Kurashiki, Japan; 3. Division of Cardiology, Saiseikai Kumamoto Hospital Cardiovascular Center, Kumamoto, Japan; 4. Department of Cardiovascular Medicine, Shiga University of Medical Science, Otsu, Japan; 5. Division of Cardiology, Osaka Saiseikai Nakatsu Hospital, Osaka, Japan; 6. Cardiovascular Medicine Center, Fukuoka Sanno Hospital, Fukuoka, Japan; 7. Division of Cardiology, Department of Internal Medicine, Teikyo University, Tokyo, Japan; 8. Division of Cardiology, Mitsui Memorial Hospital, Tokyo, Japan; 9. Medical Science Department, Daiichi Sankyo Co., Ltd., Tokyo, Japan; 10. Department of Medical Statistics, School of Medicine, Toho University, Tokyo, Japan

This paper also includes supplementary data published online at: https://eurointervention.pcronline.com/doi/10.4244/EIJ-D-20-00345

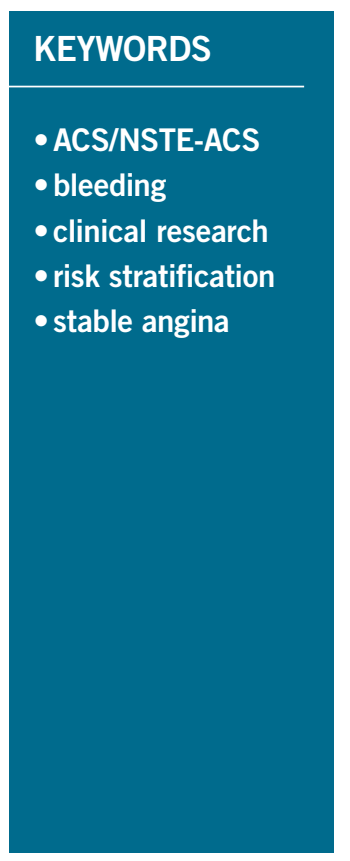

\section{Abstract}

Aims: We aimed to evaluate the validity of the Academic Research Consortium for High Bleeding Risk (ARC-HBR) criteria for East Asian patients undergoing contemporary percutaneous coronary intervention (PCI) from the PENDULUM registry.

Methods and results: This post hoc analysis included 6,267 Japanese patients undergoing PCI between December 2015 and June 2017 enrolled in PENDULUM. The primary endpoint was the incidence of major bleeding at 12 months post index PCI. In total, 3,185 (50.8\%) and 3,082 (49.2\%) patients were stratified to the ARC-HBR and non-ARC-HBR groups, respectively, and almost all patients had overlapping criteria. Incidence of major bleeding was $4.2 \%$ versus $1.4 \%$ in the ARC-HBR group versus the non-ARC-HBR group (hazard ratio 3.00 [95\% confidence interval: 2.11-4.27]; $\mathrm{p}<0.001$ ). As the number of overlapping ARC-HBR criteria increased, the incidence of major bleeding also increased. In contrast, the incidence of major bleeding was $4.2 \%$ for one major criterion, $2.1 \%$ for two minor criteria. Multivariate analysis suggested that severe CKD, anticoagulant use, acute coronary syndrome, low body weight and heart failure were independent predictors of major bleeding.

Conclusions: Half of the Japanese patients who underwent PCI in the PENDULUM registry met the ARCHBR criteria, and many patients had overlapping criteria. ARC-HBR criteria are applicable to Japanese patients undergoing contemporary PCI.

\footnotetext{
*Corresponding author: Division of Cardiovascular Medicine, Toho University Ohashi Medical Center, 2-22-36, Ohashi. Meguro-ku,Tokyo 153-8515, Japan.E-mail:masato@oha.toho-u.ac.jp
} 


\section{Abbreviations}

$\begin{array}{ll}\text { ARC } & \text { Academic Research Consortium } \\ \text { BARC } & \text { Bleeding Academic Research Consortium } \\ \text { CI } & \text { confidence interval } \\ \text { DAPT } & \text { dual antiplatelet therapy } \\ \text { DES } & \text { drug-eluting stent } \\ \text { HBR } & \text { high bleeding risk } \\ \text { HR } & \text { hazard ratio } \\ \text { ICH } & \text { intracranial haemorrhage } \\ \text { PCI } & \text { percutaneous coronary intervention } \\ \text { PPI } & \text { proton pump inhibitor }\end{array}$

\section{Introduction}

Advances in percutaneous coronary intervention (PCI)-related technologies have allowed patients with increasingly complex medical conditions to be treated with PCI, resulting in more challenging post-PCI management ${ }^{1}$. As appropriate antiplatelet therapy is a cornerstone of PCI management, assessment of thrombotic and bleeding risk is essential ${ }^{2,3}$. The Academic Research Consortium for High Bleeding Risk (ARC-HBR) initiative aimed to define HBR in patients undergoing PCI through literature review and clinical consensus, thus enabling more consistent and higher quality clinical study data collection and reporting, and facilitating appropriate clinical practice recommendations or regulatory decisions ${ }^{1,4}$. Although not fully validated, the ARC-HBR criteria are a convenient tool for use in clinical practice because they do not require scores to be calculated and include factors that are not traditionally considered as risk factors.

Previous studies in East Asian patients have reported different risk profiles for thrombosis and bleeding compared with Western patients $^{5}$. A lower dose of antiplatelet therapy was recommended for patients in Asian countries, owing to concerns with respect to a greater risk of bleeding ${ }^{6}$. However, the ARC consensus document suggests that there is a paucity of data in East Asians, stating that more research is required to elucidate the applicability of the ARC definition of HBR to Asian populations ${ }^{1}$.

The PENDULUM (Platelet rEactivity in patieNts with DrUg eLUting stent and balancing risk of bleeding and ischeMic event) registry represents contemporary PCI practice, implementing a transradial approach and proton pump inhibitors (PPIs) in daily clinical practice ${ }^{7}$. The objective of this analysis was to evaluate the applicability of ARC-HBR criteria for Japanese patients participating in the PENDULUM registry, and to explore criteria related to HBR in Japanese patients.

\section{Editorial, see page 1126}

\section{Methods}

\section{STUDY DESIGN AND PATIENT POPULATION}

The PENDULUM registry (UMIN 000020332) was a prospective, multicentre study of Japanese patients who underwent PCI in a real-world setting. The study protocol was approved by the appropriate ethics panel at each participating centre, and the study was performed in accordance with the principles of the Declaration of Helsinki and applicable Japanese guidelines. All patients provided written informed consent.

Full details of the PENDULUM registry have been described previously ${ }^{7}$ and are also provided in Supplementary Table 1. In brief, inclusion criteria were age $\geq 20$ years, an indication for PCI with a second-generation drug-eluting stent (DES), and receipt of an antiplatelet treatment. The type and dose of antiplatelet drug administered to patients were at the investigator's discretion. There were no limitations placed on the treatment of any complications arising during follow-up.

\section{ENDPOINTS}

The primary endpoint for this analysis was the cumulative incidence of major bleeding at 12 months post index PCI. Major bleeding was defined as Bleeding Academic Research Consortium (BARC) types 3 and $5^{8}$. The secondary endpoint was the cumulative incidence of intracranial haemorrhage (ICH). ICH was defined as a non-ischaemic stroke (e.g., cerebral haemorrhage, subarachnoid haemorrhage) with neurologic symptoms or with newly developed signs, and where the culprit lesion was detected by computed tomography or magnetic resonance imaging scans. Bleeding events were evaluated by independent assessment committees.

\section{ANALYSIS GROUPS AND DEFINITIONS}

The PENDULUM registry ${ }^{7}$ was a prospective registry that was initiated in 2015, prior to the publication of the ARC-HBR criteria in $2019^{1}$. Therefore, we have integrated the prospectively collected PENDULUM data into a post hoc retrospective criterion analysis; no additional data were collected for this post hoc analysis.

For the post hoc criterion analysis, enrolled patients were retrospectively stratified into HBR and non-HBR groups according to ARC-HBR criteria. However, because the PENDULUM registry was initiated prior to the ARC-HBR publication, it did not collect data on all the specified ARC-HBR criteria. Thus, for our post hoc analysis, the HBR categories were modified (Supplementary Table 2). Scores were calculated by allocating one point for each major criterion and 0.5 points for each minor criterion. The cumulative incidence of major bleeding was calculated for each ARCHBR criterion. In addition, for patients with a score of 0.5 to 1.5 , the cumulative incidence of major bleeding was calculated for each combination of criteria.

\section{STATISTICAL ANALYSIS}

For individual ARC-HBR criteria and clinically relevant variables, the one-year cumulative incidence of major bleeding and ICH was estimated using the Kaplan-Meier method. Hazard ratios (HR) and 95\% confidence intervals (CI) were generated with Cox proportional hazards regression models. Univariate and multivariate Cox proportional hazards regression models were used to identify independent predictors of major bleeding. Covariates included in the multivariate model were the ARC-HBR criteria, criteria which were considered to be clinically important, and the criteria that showed $\geq 4 \%$ cumulative incidence in the stratified 
analysis, which were not procedure-related but were clinically important. Discrimination of the bleeding risk score was assessed by $\mathrm{C}$-statistics. The area under the curve as well as predictive BARC 3 or 5 bleeding probabilities were compared. All tests were two-sided with a $5 \%$ level of significance. Statistical analyses were performed using SAS, Release 9.4 (SAS Institute, Cary, NC, USA).

\section{Results \\ PATIENT POPULATION}

A total of 6,267 patients were enrolled in the PENDULUM registry, of whom $3,185(50.8 \%)$ were in the HBR group and $3,082(49.2 \%)$ were in the non-HBR group (Figure 1A, Table 1). The overall mean age was 70 years, and $37.1 \%$ were $\geq 75$ years old. The HBR group included more patients who were older ( $\geq 75$ years), had diabetes, and did not present with acute coronary syndrome (Figure 1B, Table 1). Baseline laboratory parameters are described in Supplementary Table 3. Dual antiplatelet therapy (DAPT) was continued for 12 months after index PCI in $72.4 \%$ of HBR patients and in $84.1 \%$ of non-HBR patients $(\mathrm{p}<0.001)$. Details of DAPT adherence over time are provided in Supplementary Figure 1. Except for some factors (age $\geq 75$ years, moderate anaemia, and moderate chronic kidney disease), the proportion of patients with a single ARC-HBR criterion was only approximately $10 \%$ for each criterion; almost all patients had overlapping ARC-HBR criteria (Supplementary Figure 2).

\section{CLINICAL OUTCOME AT 12 MONTHS}

The cumulative incidence of major bleeding at 12 months post PCI was significantly higher in HBR patients than non-HBR patients (4.2\% vs 1.4\%; HR 3.00 [95\% CI: 2.11 to 4.27]; p<0.001) (Figure 2A), as was the incidence of ICH $(0.8 \%$ vs $0.5 \%$; HR 1.82
[95\% CI: 0.93 to 3.57]; $\mathrm{p}=0.083$ ) (Figure 2B). As the number of overlapping ARC-HBR criteria increased, the cumulative incidence of major bleeding also increased. In contrast, the incidence of major bleeding was $4.2 \%$ for one major criterion, $2.1 \%$ for two minor criteria (Figure 3).

When the cumulative incidence of major bleeding was stratified by ARC-HBR criteria (Figure 4), all of the ARC-HBR major criteria were associated with an incidence of major bleeding of $\geq 4 \%$; however, among patients who fulfilled a single criterion, the incidence of major bleeding was $>4 \%$ with anticoagulant use or severe anaemia (major criteria), $<4 \%$ in those with any of the other major criteria, and $<4 \%$ for each minor criterion (Figure 4 , Supplementary Table 4). The cumulative incidence of ICH stratified by ARC-HBR criteria is shown in Supplementary Figure 3. The adjusted cumulative incidences of major bleeding stratified by ARC-HBR criteria and other clinically important factors are shown in Supplementary Figure 4.

\section{REGRESSION ANALYSIS TO IDENTIFY INDEPENDENT PREDICTORS OF MAJOR BLEEDING EVENTS}

Based on the data indicating that, in addition to the ARC-HBR criteria, low body weight, heart failure, peripheral arterial disease, and non-radial approach were also associated with an incidence of major bleeding of $\geq 4 \%$, univariate and multivariate analyses were used to calculate statistically significant independent predictors of major bleeding events (Table 2).

The addition of low body weight and heart failure to the ARCHBR criteria increased the prevalence of HBR to $57.2 \%$ overall. The group of patients who met ARC-HBR criteria and had low body weight or heart failure had a significantly higher cumulative incidence of bleeding events compared with the other patient group (for major bleeding: $4.1 \%$ vs $1.2 \%$, HR 3.60 [95\% CI: 2.41

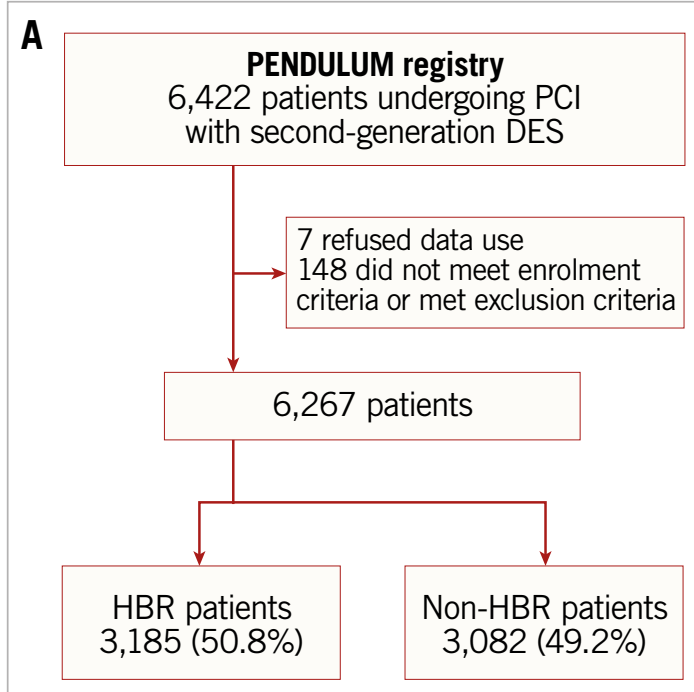

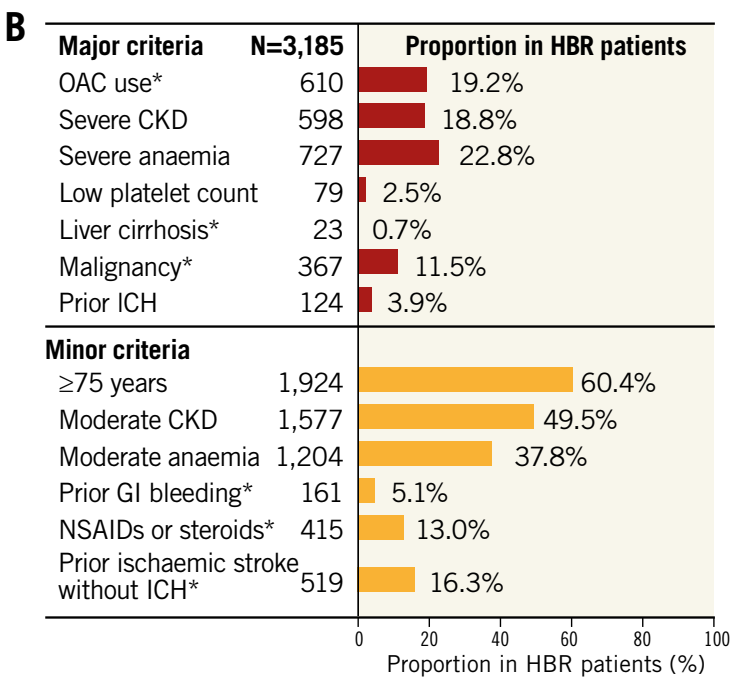

Figure 1. Patient disposition (A) and proportion of HBR patients by each ARC-HBR criterion (B). *Modified from the original ARC-HBR criteria. ARC: Academic Research Consortium; CKD: chronic kidney disease; DES: drug-eluting stent; HBR: high bleeding risk; NSAID: non-steroidal anti-inflammatory drug; OAC: oral anticoagulant; PCI: percutaneous coronary intervention 
Table 1. Baseline demographic and clinical characteristics.

\begin{tabular}{|c|c|c|c|c|c|}
\hline \multicolumn{2}{|c|}{ Characteristics } & $\begin{array}{c}\text { Total } \\
(\mathrm{N}=6,267)\end{array}$ & $\begin{array}{l}\text { ARC-HBR } \\
(n=3,185)\end{array}$ & $\begin{array}{c}\text { Non-ARC-HBR } \\
(n=3,082)\end{array}$ & $\begin{array}{l}p \text {-value (ARC-HBR } \\
\text { vs non-ARC-HBR) }\end{array}$ \\
\hline \multicolumn{2}{|l|}{ Age, years } & $70.0(10.7)$ & $74.9(9.2)$ & $65.0(9.9)$ & $<0.001$ \\
\hline \multicolumn{2}{|l|}{$\geq 75$} & $2,324(37.1)$ & $1,924(60.4)$ & $400(13.0)$ & $<0.001$ \\
\hline \multicolumn{2}{|l|}{ Sex, male } & 4,909 (78.3) & $2,332(73.2)$ & $2,577(83.6)$ & $<0.001$ \\
\hline \multicolumn{2}{|l|}{ Body weight, kg } & $64.0(12.6)$ & $60.8(12.0)$ & $67.2(12.4)$ & $<0.001$ \\
\hline \multicolumn{2}{|l|}{$\leq 50$} & $794(12.7)$ & $583(18.3)$ & $211(6.8)$ & $<0.001$ \\
\hline \multicolumn{2}{|l|}{ Body mass index, $\mathrm{kg} / \mathrm{m}^{2}$} & $24.2(3.6)$ & $23.7(3.6)$ & $24.8(3.6)$ & $<0.001$ \\
\hline \multicolumn{2}{|l|}{ Hypertension } & $5,186(82.8)$ & $2,773(87.1)$ & $2,413(78.3)$ & $<0.001$ \\
\hline \multicolumn{2}{|l|}{ Hyperlipidaemia } & $4,919(78.5)$ & $2,402(75.4)$ & $2,517(81.7)$ & $<0.001$ \\
\hline \multicolumn{2}{|l|}{ Diabetes mellitus } & $2,767(44.2)$ & $1,515(47.6)$ & $1,252(40.6)$ & $<0.001$ \\
\hline \multicolumn{2}{|l|}{ Current smoker } & $1,327(21.2)$ & $449(14.1)$ & $878(28.5)$ & $<0.001$ \\
\hline \multicolumn{2}{|l|}{ Heart failure ${ }^{a}$} & $850(13.6)$ & $642(20.2)$ & $208(6.7)$ & 0.056 \\
\hline \multicolumn{2}{|l|}{ Peripheral artery disease } & $421(6.7)$ & $324(10.2)$ & $97(3.1)$ & $<0.001$ \\
\hline \multicolumn{2}{|l|}{ Atrial fibrillation } & $538(8.6)$ & $477(15.0)$ & $61(2.0)$ & $<0.001$ \\
\hline \multicolumn{2}{|l|}{ Malignancy } & 367 (5.9) & $367(11.5)$ & $0(0.0)$ & $<0.001$ \\
\hline \multicolumn{2}{|c|}{ History of myocardial infarction } & $1,575(25.1)$ & $825(25.9)$ & $750(24.3)$ & 0.128 \\
\hline \multicolumn{2}{|c|}{ History of $\mathrm{PCl}$} & $2,567(41.0)$ & $1,361(42.7)$ & $1,206(39.1)$ & $<0.05$ \\
\hline \multicolumn{2}{|c|}{ History of coronary artery bypass grafting } & $265(4.2)$ & $179(5.6)$ & $86(2.8)$ & $<0.001$ \\
\hline \multicolumn{2}{|c|}{ History of ischaemic stroke } & $655(10.5)$ & $557(17.5)$ & $98(3.2)$ & $<0.001$ \\
\hline \multicolumn{2}{|c|}{ History of transient ischaemic attack } & $80(1.3)$ & $55(1.7)$ & $25(0.8)$ & $<0.001$ \\
\hline \multicolumn{2}{|l|}{ History of $\mathrm{ICH}$} & $124(2.0)$ & $124(3.9)$ & $0(0.0)$ & $<0.001$ \\
\hline \multicolumn{2}{|c|}{ History of gastrointestinal bleeding } & $183(2.9)$ & $161(5.1)$ & $22(0.7)$ & $<0.001$ \\
\hline \multirow[t]{5}{*}{ Clinical presentation } & Non-ACS & $4,252(67.8)$ & $2,262(71.0)$ & $1,990(64.6)$ & \multirow{2}{*}{$<0.001$} \\
\hline & ACS & 2,015 (32.2) & $923(29.0)$ & $1,092(35.4)$ & \\
\hline & Unstable angina & $790(12.6)$ & $387(12.2)$ & $403(13.1)$ & 0.270 \\
\hline & Non-STEMI & $323(5.2)$ & $165(5.2)$ & $158(5.1)$ & 80 \\
\hline & STEMI & $908(14.5)$ & $373(11.7)$ & $535(17.4)$ & $<0.05$ \\
\hline Medication at discharge & Thienopyridine & 6,195 (98.9) & $3,129(98.2)$ & $3,066(99.5)$ & $<0.001$ \\
\hline & Clopidogrel & $2,213(35.3)$ & $1,333(41.9)$ & $880(28.6)$ & 1 \\
\hline & Prasugrel & $3,921(62.6)$ & $1,756(55.1)$ & $2,165(70.2)$ & $<0.001$ \\
\hline & Aspirin & $6,143(98.0)$ & $3,092(97.1)$ & 3,051 (99.0) & $<0.001$ \\
\hline & OAC & $610(9.7)$ & $610(19.2)$ & $0(0.0)$ & $<0.001$ \\
\hline & Proton pump inhibitor & $5,295(84.5)$ & $2,679(84.1)$ & $2,616(84.9)$ & 0.402 \\
\hline & \begin{tabular}{|l|} 
NSAIDs except aspirin \\
\end{tabular} & $334(5.3)$ & $259(8.1)$ & $75(2.4)$ & $<0.001$ \\
\hline & Steroids & $250(4.0)$ & $198(6.2)$ & $52(1.7)$ & $<0.001$ \\
\hline
\end{tabular}

to 5.38], $\mathrm{p}<0.001$; for ICH: $0.9 \%$ vs $0.4 \%$, HR 2.37 [95\% CI: 1.12 to 5.02], $\mathrm{p}<0.05$ ) (Supplementary Figure 5). The $\mathrm{C}$-indices did not improve when low body weight and heart failure were added into the ARC-HBR criteria; however, both ARC-HBR and ARC-HBR with low body weight and heart failure had higher sensitivity (but lower specificity) in estimating the occurrence of major bleeding. The PARIS major bleeding score had higher specificity than sensitivity (Supplementary Figure 6).

\section{Discussion}

This study was the first to investigate the suitability of ARC-HBR in $>6,000$ Japanese patients receiving second-generation DES and enrolled in the PENDULUM real-world registry. The main findings of this study are the following: (i) approximately $50 \%$ of the Japanese patients who underwent PCI were classified as ARCHBR patients, and the majority of HBR patients had overlapping criteria; (ii) the ARC-HBR criteria were suitable for Japanese patients in the contemporary PCI era, where patients are commonly managed with strategies such as lower doses of antiplatelet drugs ${ }^{6}$, a transradial PCI approach ${ }^{9}$, and use of PPIs; (iii) the multivariate regression analysis suggested that low body weight and heart failure are predictive factors for high bleeding risk but $\mathrm{C}$-indices were not improved.

Ueki et al recently reported that approximately $40 \%$ of patients from the Bern Registry fulfilled the ARC-HBR criteria ${ }^{10}$. In the present study, $50.8 \%$ of patients $(3,185 / 6,267)$ were found to have 
A

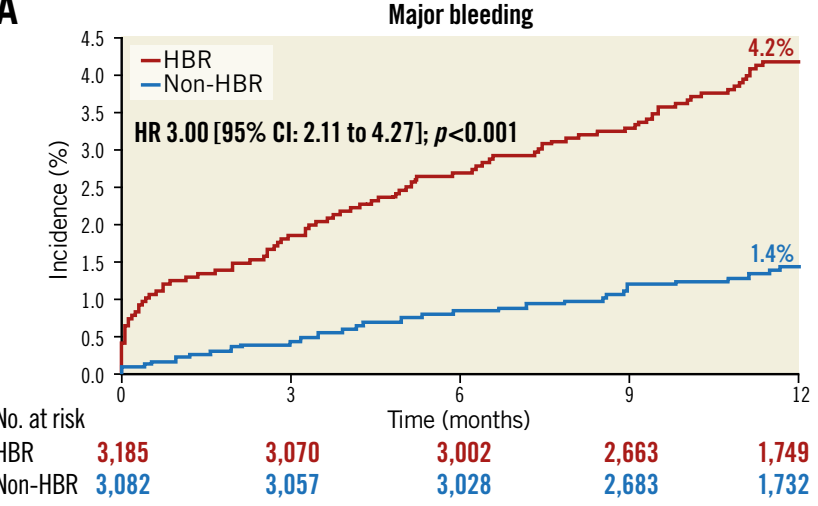

B

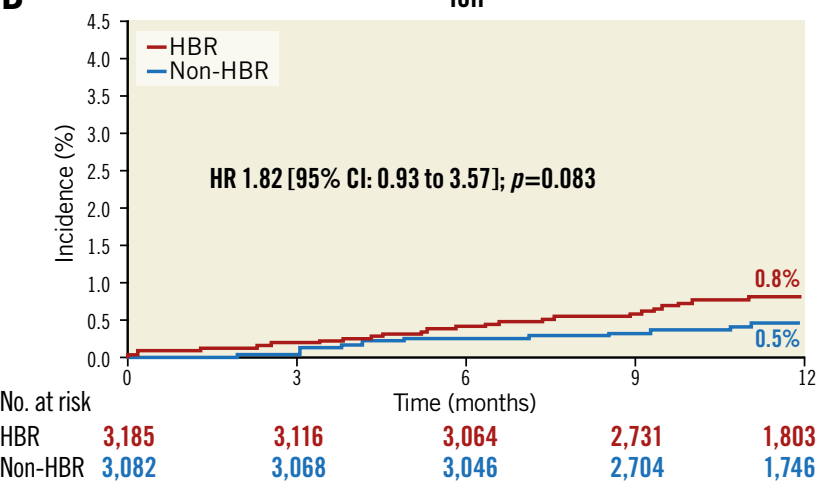

Figure 2. Cumulative incidence of major bleeding (A) and ICH (B) by ARC-HBR status. CI: confidence interval; HBR: high bleeding risk; HR: hazard ratio; ICH: intracranial haemorrhage

HBR. In previous reports, the proportion of HBR patients in Japan has been reported to be $43 \%{ }^{11}$. Taken together, it can be assumed that the incidence of HBR is approximately $50 \%$ in Japanese daily practice. Patient characteristics were similar between our study and those in the Bern Registry; however, the proportion of patients with overlapping bleeding risk criteria was higher in our study than in the Bern Registry. Only 244 (3.9\%) patients had a single major ARC-HBR criterion even though the prevalence of HBR was $51 \%$ in this study. Of 4,781 HBR patients, $799(16.7 \%)$ had a single major ARC-HBR criterion in the Bern Registry ${ }^{10}$. This may suggest that Japanese patients are more likely to have overlapping risk factors. The elucidation of the real impact of each minor criterion warrants further study.

The incidence of major bleeding in our study was lower than that in previous studies. In the Bern Registry, the risk of BARC 3 or 5 bleeding was $6.4 \%$ in the HBR group and $1.9 \%$ in the nonHBR group ${ }^{10}$, and in the CREDO-Kyoto registry cohort- $2^{11}$ the risk of major bleeding was $10.4 \%$ versus $3.4 \%$, respectively. There are several explanations as to why these differences might be possible. Firstly, the difference in patient demographics should be considered. It is well known that the incidence of major bleeding is higher in acute coronary syndrome patients. In the present study, the proportion of acute coronary syndrome patients was limited to almost $30 \%$ compared with almost $50 \%$ in the Bern Registry study. In addition, IIb/IIIa antagonist treatment is not available in
A

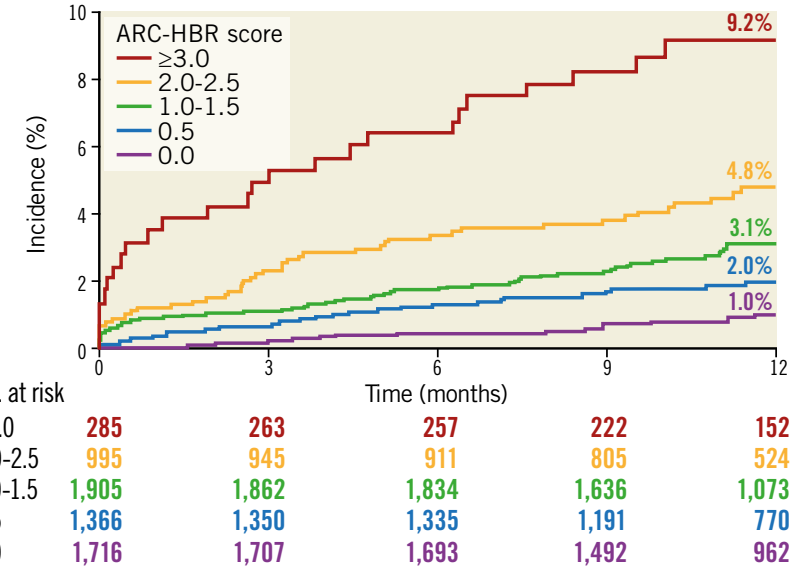

B

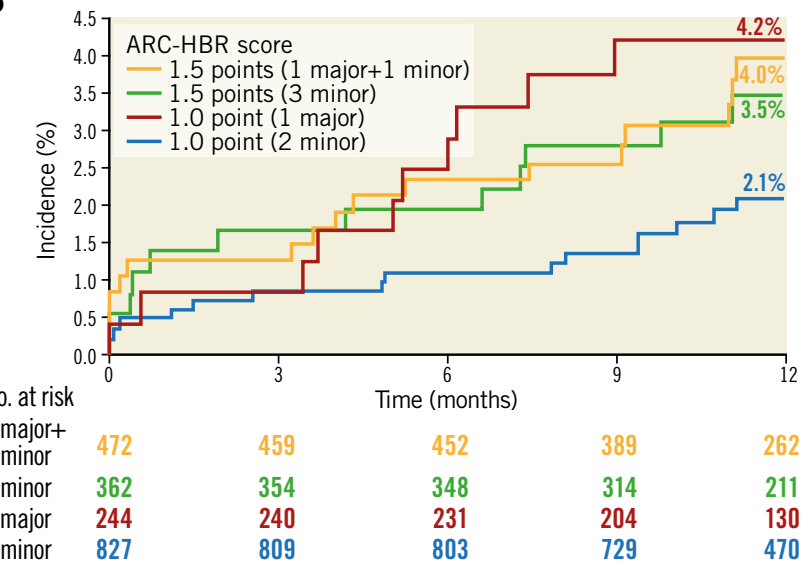

Figure 3. Cumulative incidence of major bleeding by ARC-HBR score categories; 0 to $\geq 3.0$ points (A), and 1 to 1.5 points $(B)$. ARC: Academic Research Consortium; HBR: high bleeding risk

Japan and the approved doses of antiplatelet regimens in Japan differ from those in other countries. Secondly, technical advances coupled with the improvement of medical management might contribute to the reduction of bleeding risk. It should be noted that the CREDO-Kyoto registry cohort- 2 is almost 10 years old, and the procedures and medications used ${ }^{11,12}$ were different from those used in the present study. Additionally, the hazard risk of bleeding in HBR patients compared to non-HBR patients (three times higher) was in line with the CREDO-Kyoto registry cohort-2 and the Bern Registry.

All of the ARC-HBR major criteria were found to be associated with an incidence of major bleeding $\geq 4 \%$ at one year. The same observation was made in patients who met isolated major criteria of anticoagulant use at discharge or severe anaemia. In our analysis, the incidence of major bleeding in patients with ARC-HBR scores of $1-1.5$ was $3.1 \%$ (i.e., lower than $4 \%$ ). Our results showed that, as the number of overlapping ARC-HBR criteria increased, the cumulative incidence of major bleeding also increased in East Asian patients, which was in line with the recent findings reported by Cao et $\mathrm{al}^{13}$. The incidence of major bleeding in patients with only one major criterion was $4.2 \%$, while that in those with two 
Table 2. Univariate and multivariate regression analysis of major bleeding at one year.

\begin{tabular}{|c|c|c|c|c|c|c|}
\hline \multirow{2}{*}{\multicolumn{2}{|c|}{ Variable }} & \multirow{2}{*}{ Events (\%) } & \multicolumn{2}{|c|}{ Univariate } & \multicolumn{2}{|c|}{ Multivariate } \\
\hline & & & HR & $95 \%$ CI & HR & $95 \% \mathrm{Cl}$ \\
\hline \multicolumn{2}{|l|}{ Age, years; $\geq 75$} & $82(3.5)$ vs $83(2.1)$ & 1.714 & $1.263-2.325$ & 0.991 & $0.656-1.497$ \\
\hline \multicolumn{2}{|l|}{ Sex; male } & $124(2.5)$ vs 41 (3.0) & 0.828 & $0.581-1.178$ & 1.292 & $0.793-2.102$ \\
\hline \multicolumn{2}{|l|}{ Body weight, $\mathrm{kg} ; \leq 50$} & 39 (4.9) vs 120 (2.3) & 2.260 & $1.574-3.243$ & 1.849 & $1.125-3.039$ \\
\hline \multicolumn{2}{|l|}{ Hypertension } & $142(2.7)$ vs $23(2.1)$ & 1.272 & 0.819-1.976 & 0.980 & $0.586-1.639$ \\
\hline \multicolumn{2}{|l|}{ Diabetes mellitus } & $66(2.4)$ vs 99 (2.8) & 0.846 & $0.620-1.155$ & 0.772 & $0.526-1.135$ \\
\hline \multicolumn{2}{|l|}{ Current smoker } & 32 (1.9) vs 109 (2.8) & 0.694 & $0.468-1.029$ & 0.756 & $0.478-1.193$ \\
\hline \multicolumn{2}{|l|}{ Heart failure } & $49(5.8)$ vs $116(2.1)$ & 2.813 & $2.014-3.928$ & 1.871 & $1.219-2.872$ \\
\hline \multicolumn{2}{|l|}{ Peripheral arterial disease } & $19(4.5)$ vs $146(2.5)$ & 1.824 & $1.131-2.943$ & 1.437 & $0.806-2.560$ \\
\hline \multicolumn{2}{|l|}{ Malignancy } & $16(4.4)$ vs $149(2.5)$ & 1.787 & $1.067-2.992$ & 1.338 & $0.690-2.595$ \\
\hline \multicolumn{2}{|l|}{ Liver cirrhosis } & 1 (4.3) vs $164(2.6)$ & 1.734 & $0.243-12.384$ & 1.388 & $0.183-10.548$ \\
\hline \multicolumn{2}{|c|}{ History of ischaemic stroke without ICH } & 19 (3.1) vs 135 (2.5) & 1.247 & $0.772-2.016$ & - & - \\
\hline \multicolumn{2}{|l|}{ History of ICH } & $6(4.8)$ vs $148(2.5)$ & 1.950 & $0.862-4.410$ & - & - \\
\hline \multicolumn{2}{|c|}{ History of ischaemic stroke or $\mathrm{ICH}$} & 25 (3.4) vs 129 (2.4) & 1.399 & $0.912-2.147$ & 1.059 & $0.639-1.753$ \\
\hline \multicolumn{2}{|c|}{ History of gastrointestinal bleeding } & 8 (4.4) vs $142(2.5)$ & 1.802 & $0.884-3.674$ & 1.228 & $0.535-2.818$ \\
\hline \multicolumn{2}{|l|}{ ACS } & $56(2.8)$ vs 109 (2.6) & 1.105 & $0.800-1.525$ & 1.480 & $1.010-2.169$ \\
\hline \multirow{2}{*}{$\begin{array}{l}\text { Haemoglobina, } \\
\text { g/dL }\end{array}$} & $<11$ & $41(5.6)$ vs $69(1.7)$ & 3.388 & $2.302-4.986$ & 1.756 & $1.022-3.017$ \\
\hline & $\begin{array}{l}\text { Male: } \geq 11 \text { to }<13 ; \\
\text { Female: } \geq 11 \text { to }<12\end{array}$ & 49 (3.5) vs 69 (1.7) & 2.017 & $1.398-2.909$ & 1.529 & $0.984-2.377$ \\
\hline \multirow{2}{*}{$\begin{array}{l}\text { eGFR } \\
\mathrm{mL} / \mathrm{min} / 1.73 \mathrm{~m}^{2}\end{array}$} & $<30$ & $39(6.5)$ vs $59(1.7)$ & 3.991 & $2.663-5.981$ & 1.999 & $1.131-3.534$ \\
\hline & $\geq 30$ to $<60$ & $65(3.1)$ vs $59(1.7)$ & 1.823 & $1.282-2.594$ & 1.274 & $0.827-1.961$ \\
\hline \multicolumn{2}{|c|}{ Platelet count, $\times 10^{4} / \mu \mathrm{L} ;<10$} & $4(5.1)$ vs $154(2.6)$ & 2.129 & $0.789-5.740$ & 1.339 & $0.412-4.354$ \\
\hline \multirow{2}{*}{$\begin{array}{l}\text { PRU value for } \\
12-48 \text { hours after initial } \\
\mathrm{PCl}\end{array}$} & $>208$ & $66(3.0)$ vs $88(2.4)$ & 1.250 & $0.908-1.719$ & - & - \\
\hline & $>85$ & 135 (2.6) vs 19 (2.8) & 0.918 & $0.568-1.484$ & - & - \\
\hline \multicolumn{2}{|l|}{ Puncture site; except radial } & $72(3.8)$ vs $93(2.1)$ & 1.825 & $1.342-2.482$ & - & - \\
\hline \multicolumn{2}{|l|}{ Complex PCl } & 40 (3.1) vs 125 (2.5) & 1.262 & $0.884-1.802$ & - & - \\
\hline \multicolumn{2}{|l|}{ Anticoagulant at discharge } & $38(6.2)$ vs $127(2.2)$ & 2.834 & $1.973-4.072$ & 2.506 & $1.619-3.879$ \\
\hline \multicolumn{2}{|c|}{ NSAIDs or steroids at discharge } & $24(4.5)$ vs 141 (2.5) & 1.825 & $1.184-2.813$ & 1.381 & $0.772-2.471$ \\
\hline
\end{tabular}

minor criteria was $2.1 \%$, suggesting that the contribution of minor criteria to bleeding risk can be considered. The incidence of major bleeding was $7.6 \%$ and $6.0 \%$ in patients who met a single criterion of "use of anticoagulant at discharge" and "severe anaemia", respectively. Owing to the overlap of multiple HBR criteria in this cohort, the study is underpowered to evaluate the incidence of major bleeding in patients who met each criterion alone. To adjust the confounders, Cox regression analysis was performed. Severe chronic kidney disease, anticoagulant use at discharge, acute coronary syndrome, low body weight $(\leq 50 \mathrm{~kg})$, and heart failure were found to be independent risk factors.

A history of heart failure has been reported as an independent predictor of bleeding in the PENDULUM registry and CREDOKyoto registry cohort- $2^{7,11}$. This is likely to be related to the higher mean ages of enrolled patients in the PENDULUM registry and in the CREDO-Kyoto registry cohort-2 (70.0 and 68.2 years, respectively) $)^{7,11}$, compared with other registries discussed in the original ARC-HBR paper ${ }^{1}$. However, as our results are based on a post hoc analysis, the findings should be interpreted with caution. Indeed, most cases that met an isolated criterion did not demonstrate an incidence of major bleeding $>4 \%$ and the cumulative incidence of major bleeding was similar. Furthermore, C-statistics did not improve with the addition of these factors. Further studies are warranted to assess the clinical impact of these factors in predicting major bleeding.

When comparing the HBR and non-HBR groups, there was a statistically significant difference in DAPT duration. Whether antiplatelet drug de-escalation is effective in reducing bleeding would require hypothetical testing. Even in patients with HBR, DAPT was used in $70 \%$ of patients after 12 months, and bleeding events were observed frequently. This strongly suggests that there is room for improvement. 


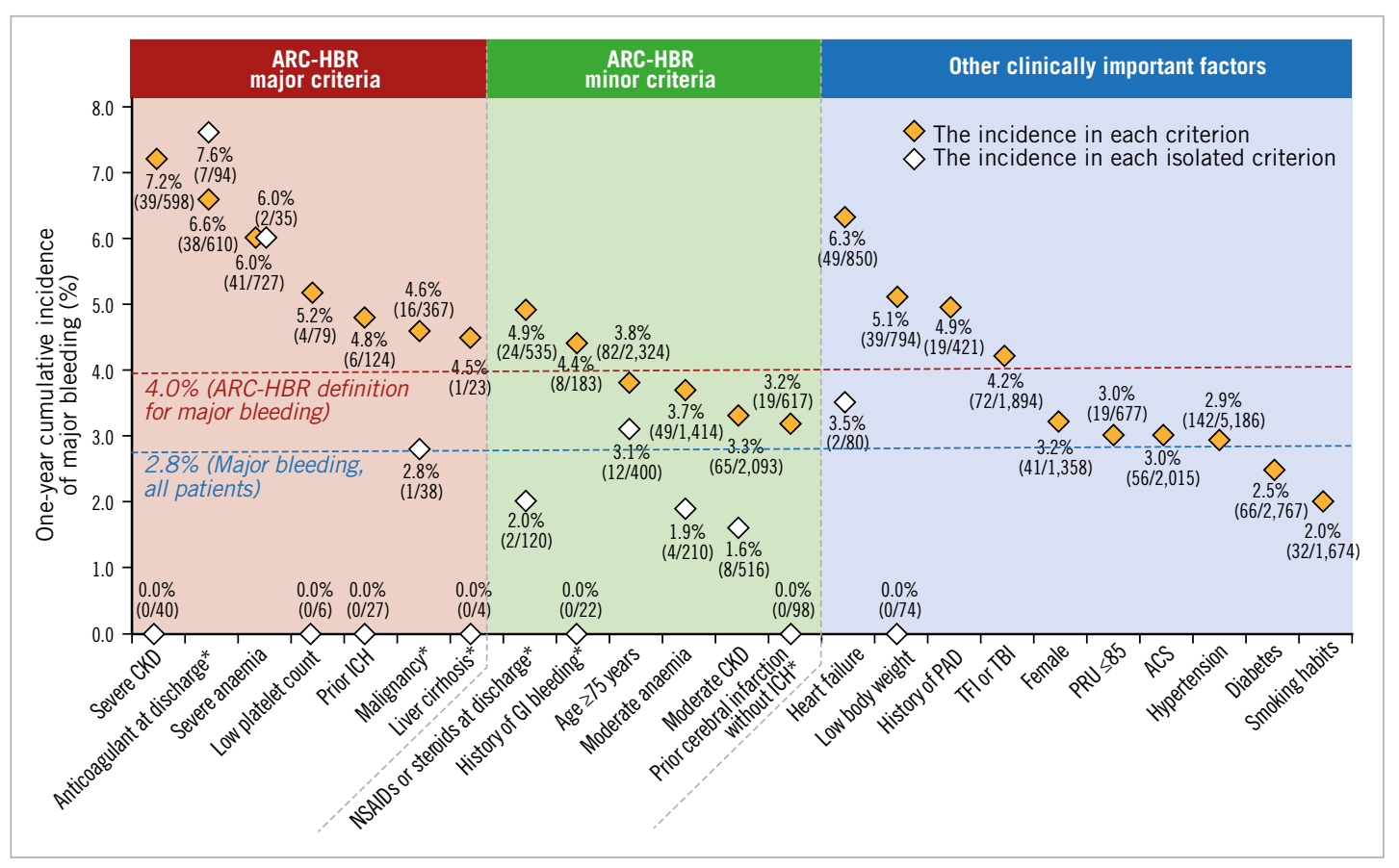

Figure 4. Cumulative incidence of major bleeding by each ARC-HBR criterion and other clinically important factors. *Modified from the original ARC-HBR criteria. ACS: acute coronary syndrome; ARC: Academic Research Consortium; CKD: chronic kidney disease; GI: gastrointestinal; HBR: high bleeding risk; ICH: intracranial haemorrhage; PAD: peripheral arterial disease; PRU: platelet reactivity unit; TBI: transbrachial intervention; TFI: transfemoral intervention

\section{Limitations}

This analysis has some limitations. First, the post hoc nature of the analysis means that not all variables from the original ARCHBR definitions were collected, and we were unable to address some criteria (e.g., chronic bleeding diathesis and recent major surgery or major trauma within 30 days prior to PCI). The differences in the original ARC-HBR criteria and the modified version used in our analysis mean that the data from our study may not be directly comparable to other publications assessing HBR, limiting their clinical utility. Importantly, many of the ARC-HBR criteria were not available or were markedly modified, including our definition of gastrointestinal bleeding, which did not include hospitalisations or transfusion treatment. The incidence of bleeding was $>4 \%$ in patients with prior gastrointestinal bleeding; therefore, it was included as a minor criterion in our study. Second, selection bias was inevitable, because this study was an observational study and not all patients undergoing PCI at each institution could be enrolled. Third, ARC-HBR defined major bleeding incidence as $\geq 4 \%$; however, because East Asian and Western patients are reported to have different risk profiles for bleeding and thrombosis ${ }^{5}, 4 \%$ may not be a suitable cut-off for Japanese patients. This requires further study. Fourth, all patients enrolled in this study were Japanese and, thus, the results may not be completely generalisable to other East Asian populations. Fifth, we did not use a quantitative description for heart failure in our study (e.g., ejection fraction). Instead, we defined heart failure based on hospitalisation or having a treatment history. Finally, the present study focused on the risk of bleeding in Japanese patients and did not assess the risk of cardiovascular events or mortality, although we can assume that such risks are also increased in patients with HBR. Further analysis is needed to understand and manage these additional clinical risks in HBR patients.

\section{Conclusions}

In conclusion, this analysis showed that half of the Japanese patients who underwent $\mathrm{PCI}$ in the PENDULUM registry met ARC-HBR criteria, and many had overlapping criteria. The ARCHBR criteria are applicable to Japanese patients undergoing contemporary PCI.

\section{Impact on daily practice}

Appropriate management strategies for patients with high bleeding risk (HBR) requiring dual antiplatelet therapy after percutaneous coronary intervention have not been fully established, particularly in East Asian patients, who have a different risk profile to Western patients. This analysis showed that the Academic Research Consortium (ARC) for HBR criteria are appropriate for estimation of bleeding risk in Japanese patients. Half of the Japanese patients who underwent PCI in the PENDULUM registry met the ARC-HBR criteria, and many patients had overlapping criteria. 


\section{Acknowledgements}

We thank Sheridan Henness, PhD, of Edanz Evidence Generation for providing medical writing support, which was funded by Daiichi Sankyo Co., Ltd.

\section{Funding}

This study was supported by Daiichi Sankyo Co., Ltd., Tokyo, Japan. Daiichi Sankyo Co., Ltd. played a role in the design and conduct of the study; collection, management, analysis, and interpretation of the data; preparation, review, or approval of the manuscript; and decision to submit the manuscript for publication.

\section{Conflict of interest statement}

M. Nakamura has received grants from Daiichi Sankyo Co., Ltd., Sanofi K.K., and Bayer K.K., and other fees from Daiichi Sankyo Co., Ltd., Sanofi K.K., Terumo Corporation, and Bristol Myers Squibb K.K. K. Kadota has received personal fees from Daiichi Sankyo Co., Ltd., and Sanofi K.K. K. Nakao has received personal fees from Daiichi Sankyo Co., Ltd. Y. Nakagawa has received personal fees from Bristol Myers Squibb K.K. and Kowa Pharmaceutical Co., Ltd., and grants and personal fees from Daiichi Sankyo Co., Ltd., Bayer Yakuhin, Ltd., Sanofi K.K., Boston Scientific Corporation, and Abbott Vascular Japan Co., Ltd. J. Shite has received personal fees from Daiichi Sankyo Co., Ltd., Nipro, Abbott, and Terumo Corporation. H. Yokoi has received personal fees from Daiichi Sankyo Co., Ltd., Bayer K.K., and Sanofi K.K. K. Kozuma has received grants and personal fees from Daiichi Sankyo Co., Ltd. K. Tanabe has received personal fees from Daiichi Sankyo Co., Ltd., Sanofi K.K., AstraZeneca, Abbott Vascular Japan, Co., Ltd., Boston Scientific Corporation, and Terumo Corporation. R. Iijima has received personal fees from Daiichi Sankyo Co., Ltd. A. Harada and T. Kuroda are employees of Daiichi Sankyo Co., Ltd. Y. Murakami has received personal fees from Daiichi Sankyo Co., Ltd., SRD Co., Ltd., and Sanofi K.K.

\section{References}

1. Urban P, Mehran R, Colleran R, Angiolillo DJ, Byrne RA, Capodanno D, Cuisset T, Cutlip D, Eerdmans P, Eikelboom J, Farb A, Gibson CM, Gregson J, Haude M, James SK, Kim HS, Kimura T, Konishi A, Laschinger J, Leon MB, Magee PFA, Mitsutake Y, Mylotte D, Pocock S, Price MJ, Rao SV, Spitzer E, Stockbridge N, Valgimigli M, Varenne O, Windhoevel U, Yeh RW, Krucoff MW, Morice MC. Defining High Bleeding Risk in Patients Undergoing Percutaneous Coronary Intervention. Circulation. 2019;140:240-61.

2. Levine GN, Bates ER, Bittl JA, Brindis RG, Fihn SD, Fleisher LA, Granger CB, Lange RA, Mack MJ, Mauri L, Mehran R, Mukherjee D, Newby LK, O'Gara PT, Sabatine MS, Smith PK, Smith SC Jr. 2016 ACC/AHA Guideline Focused Update on Duration of Dual Antiplatelet Therapy in Patients With Coronary Artery Disease: A Report of the American College of Cardiology/American Heart Association Task Force on Clinical Practice Guidelines. J Am Coll Cardiol. 2016;68:1082-115.

3. Valgimigli M, Bueno H, Byrne RA, Collet JP, Costa F, Jeppsson A, Jüni P, Kastrati A, Kolh P, Mauri L, Montalescot G, Neumann FJ, Petricevic M, Roffi M, Steg PG, Windecker S, Zamorano JL, Levine GN; ESC Scientific Document Group; ESC Committee for Practice Guidelines (CPG); ESC National Cardiac Societies. 2017 ESC focused update on dual antiplatelet therapy in coronary artery disease developed in collaboration with EACTS:
The Task Force for dual antiplatelet therapy in coronary artery disease of the European Society of Cardiology (ESC) and of the European Association for Cardio-Thoracic Surgery (EACTS). Eur Heart J. 2018;39:213-60.

4. Krucoff MW, Mehran R, van Es GA, Boam AB, Cutlip DE. The academic research consortium governance charter. JACC Cardiovasc Interv. 2011;4:595-6.

5. Levine GN, Jeong YH, Goto S, Anderson JL, Huo Y, Mega JL, Taubert K, Smith SC Jr. Expert consensus document: World Heart Federation expert consensus statement on antiplatelet therapy in East Asian patients with ACS or undergoing PCI. Nat Rev Cardiol. 2014;11:597-606.

6. Saito S, Isshiki T, Kimura T, Ogawa H, Yokoi H, Nanto S, Takayama M, Kitagawa K, Nishikawa M, Miyazaki S, Nakamura M. Efficacy and safety of adjusted-dose prasugrel compared with clopidogrel in Japanese patients with acute coronary syndrome: the PRASFIT-ACS study. Circ J. 2014;78:1684-92.

7. Nakamura M, Kadota K, Takahashi A, Kanda J, Anzai H, Ishii Y, Shibata Y, Yasaka Y, Takamisawa I, Yamaguchi J, Takeda Y, Harada A, Motohashi T, Iijima R, Uemura S, Murakami Y; PENDULUM Registry Investigators*. Relationship Between Platelet Reactivity and Ischemic and Bleeding Events After Percutaneous Coronary Intervention in East Asian Patients: 1-Year Results of the PENDULUM Registry. J Am Heart Assoc. 2020;9:e015439.

8. Mehran R, Rao SV, Bhatt DL, Gibson CM, Caixeta A, Eikelboom J, Kaul S, Wiviott SD, Menon V, Nikolsky E, Serebruany V, Valgimigli M, Vranckx P, Taggart D, Sabik JF, Cutlip DE, Krucoff MW, Ohman EM, Steg PG, White H. Standardized bleeding definitions for cardiovascular clinical trials: a consensus report from the Bleeding Academic Research Consortium. Circulation. 2011; 123:2736-47.

9. Fujii T, Ikari Y, Hashimoto H, Kadota K, Amano T, Uemura S, Takashima H, Nakamura M, J-PCI Investigators. Post-interventional adverse event risk by vascular access site among patients with acute coronary syndrome in Japan: observational analysis with a national registry J-PCI database. Cardiovasc Interv Ther. 2019;34:297-304.

10. Ueki Y, Bar S, Losdat S, Otsuka T, Zanchin C, Zanchin T, Gragnano F, Gargiulo G, Siontis GCM, Praz F, Lanz J, Hunziker L, Stortecky S, Pilgrim T, Heg D, Valgimigli M, Windecker S, Räber L. Validation of the Academic Research Consortium for High Bleeding Risk (ARC-HBR) criteria in patients undergoing percutaneous coronary intervention and comparison with contemporary bleeding risk scores. EuroIntervention. 2020;16:371-9.

11. Kimura T, Morimoto T, Furukawa Y, Nakagawa Y, Kadota K, Iwabuchi M, Shizuta S, Shiomi H, Tada T, Tazaki J, Kato Y, Hayano M, Abe M, Tamura T, Shirotani M, Miki S, Matsuda M, Takahashi M, Ishii K, Tanaka M, Aoyama T, Doi O, Hattori R, Tatami R, Suwa S, Takizawa A, Takatsu Y, Takahashi M, Kato H, Takeda T, Lee JD, Nohara R, Ogawa H, Tei C, Horie M, Kambara H, Fujiwara H, Mitsudo K, Nobuyoshi M, Kita T. Long-term safety and efficacy of sirolimus-eluting stents versus bare-metal stents in real world clinical practice in Japan. Cardiovasc Interv Ther. 2011;26:234-45.

12. Natsuaki M, Morimoto T, Shiomi H, Yamaji K, Watanabe H, Shizuta S, Kato T, Ando K, Nakagawa Y, Furukawa Y, Tada T, Nagao K, Kadota K, Toyofuku M, Kimura T. Application of the Academic Research Consortium high bleeding risk criteria in an all-comers registry of percutaneous coronary intervention. Circ Cardiovasc Interv. 2019;12:e008307.

13. Cao D, Mehran R, Dangas G, Baber U, Sartori S, Chandiramani R, Stefanini GG, Angiolillo DJ, Capodanno D, Urban P, Morice MC, Krucoff M, Goel R, Roumeliotis A, Sweeny J, Sharma SK, Kini A. Validation of the Academic Research Consortium High Bleeding Risk Definition in Contemporary PCI Patients. J Am Coll Cardiol. 2020;75:2711-22.

\section{Supplementary data}

Supplementary Figure 1. Proportion of patients who continued to receive DAPT over time.

Supplementary Figure 2. Proportion of patients who fulfilled each ARC-HBR criterion. 
Supplementary Figure 3. Cumulative incidence of ICH stratified by ARC-HBR criteria and other clinically important factors.

Supplementary Figure 4. Adjusted cumulative incidence of major bleeding stratified by ARC-HBR criteria and other clinically important factors.

Supplementary Figure 5. Cumulative incidence of major bleeding (A) and intracranial haemorrhage (B) by ARC-HBR criteria plus low body weight and heart failure.

Supplementary Figure 6. Receiver operating characteristic curve analysis of major bleeding (A) and intracranial haemorrhage (B) for each bleeding risk criteria category.
Supplementary Table 1. Full methodological details of the PENDULUM (Platelet rEactivity in patieNts with DrUg eLUting stent and balancing risk of bleeding and ischeMic event) registry study ${ }^{7}$. Supplementary Table 2. High bleeding risk definitions.

Supplementary Table 3. Baseline laboratory parameters.

Supplementary Table 4 . The proportion of events in each combination of criteria.

The supplementary data are published online at: https://eurointervention.pcronline.com/ doi/10.4244/EIJ-D-20-00345 


\section{Supplementary data}

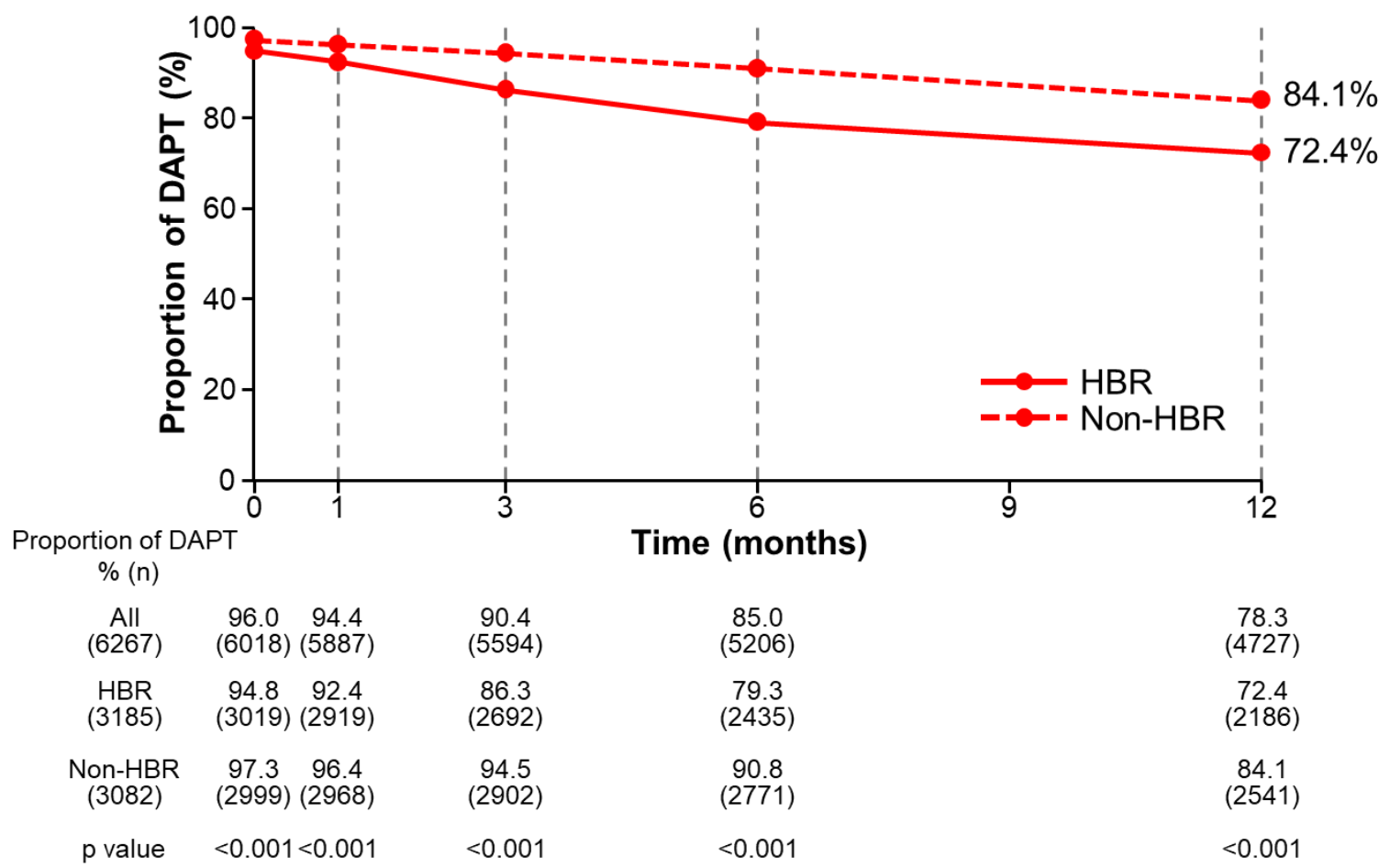

Supplementary Figure 1. Proportion of patients who continued to receive DAPT over time.

DAPT: dual antiplatelet therapy; HBR: high bleeding risk 


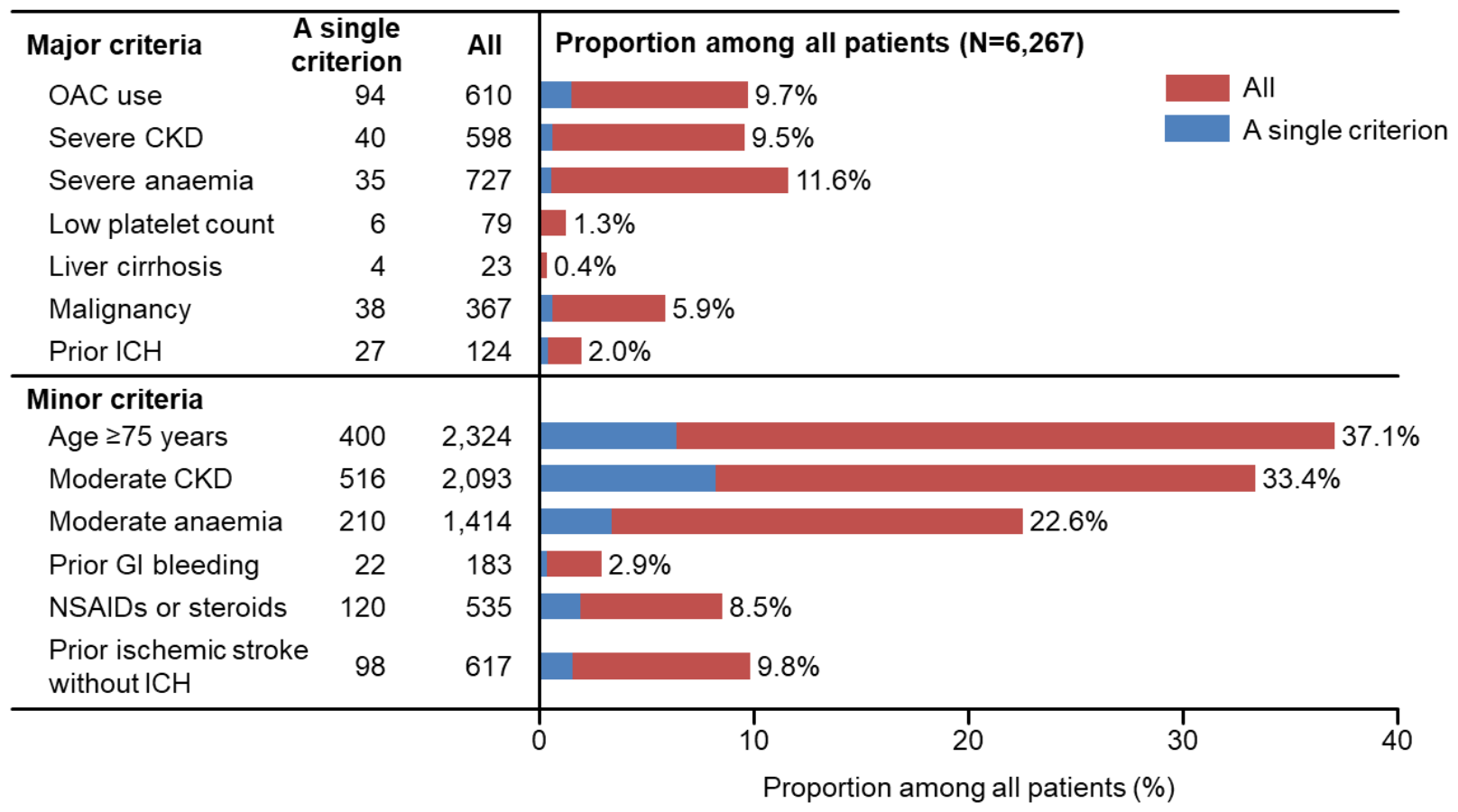

Supplementary Figure 2. Proportion of patients who fulfilled each ARC-HBR criterion.

ARC: Academic Research Consortium; CKD: chronic kidney disease; GI: gastrointestinal; ICH:

intracranial haemorrhage; NSAIDs: non-steroidal anti-inflammatory drugs; OAC: oral anticoagulant 


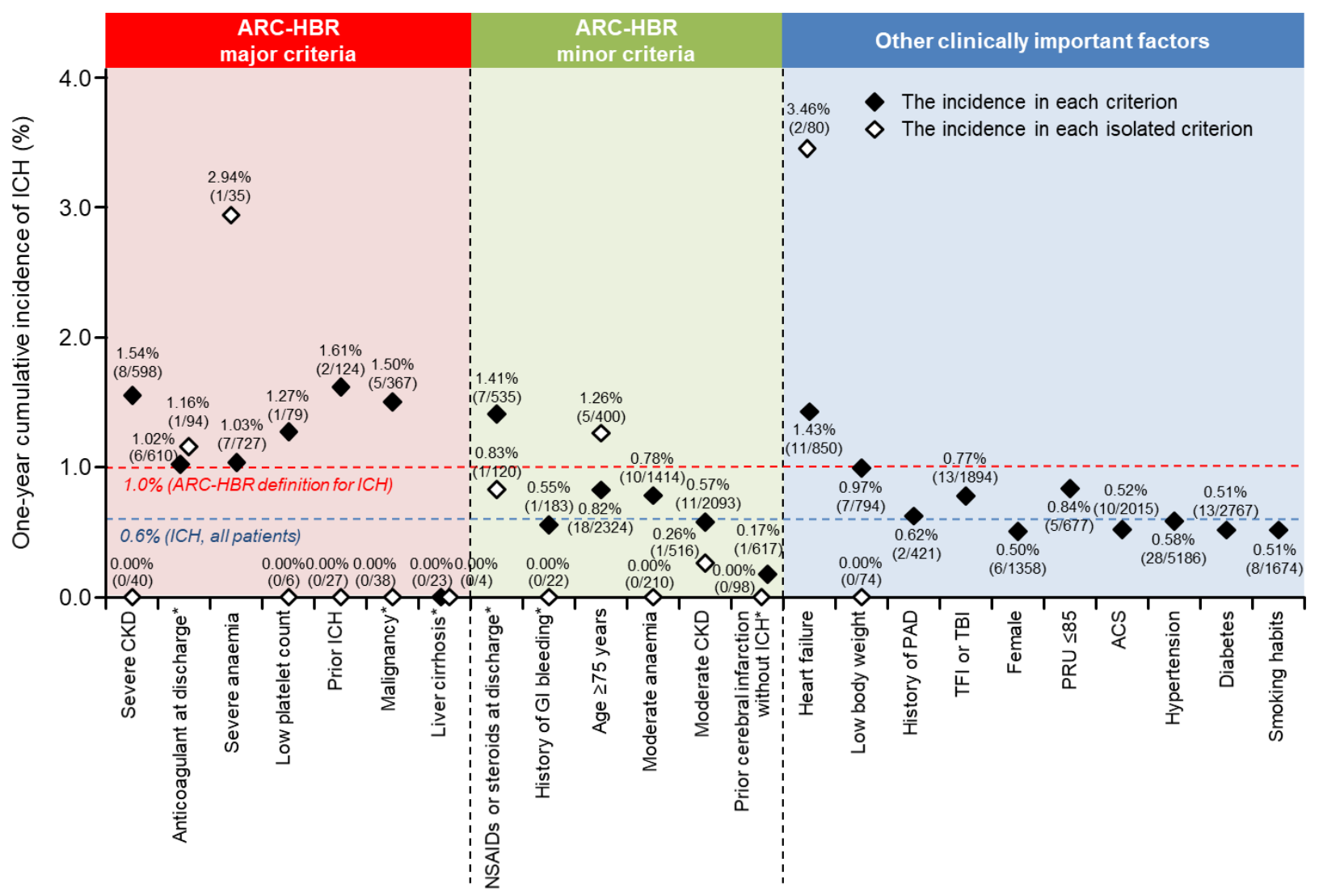

Supplementary Figure 3. Cumulative incidence of ICH stratified by ARC-HBR criteria and other clinically important factors.

*Modified from the original ARC-HBR criteria.

ACS: acute coronary syndrome; ARC: Academic Research Consortium; CKD: chronic kidney disease;

GI: gastrointestinal; HBR: high bleeding risk; ICH: intracranial haemorrhage; PAD: peripheral arterial disease; PRU: platelet reactivity unit; TBI: transbrachial intervention; TFI: transfemoral intervention. 


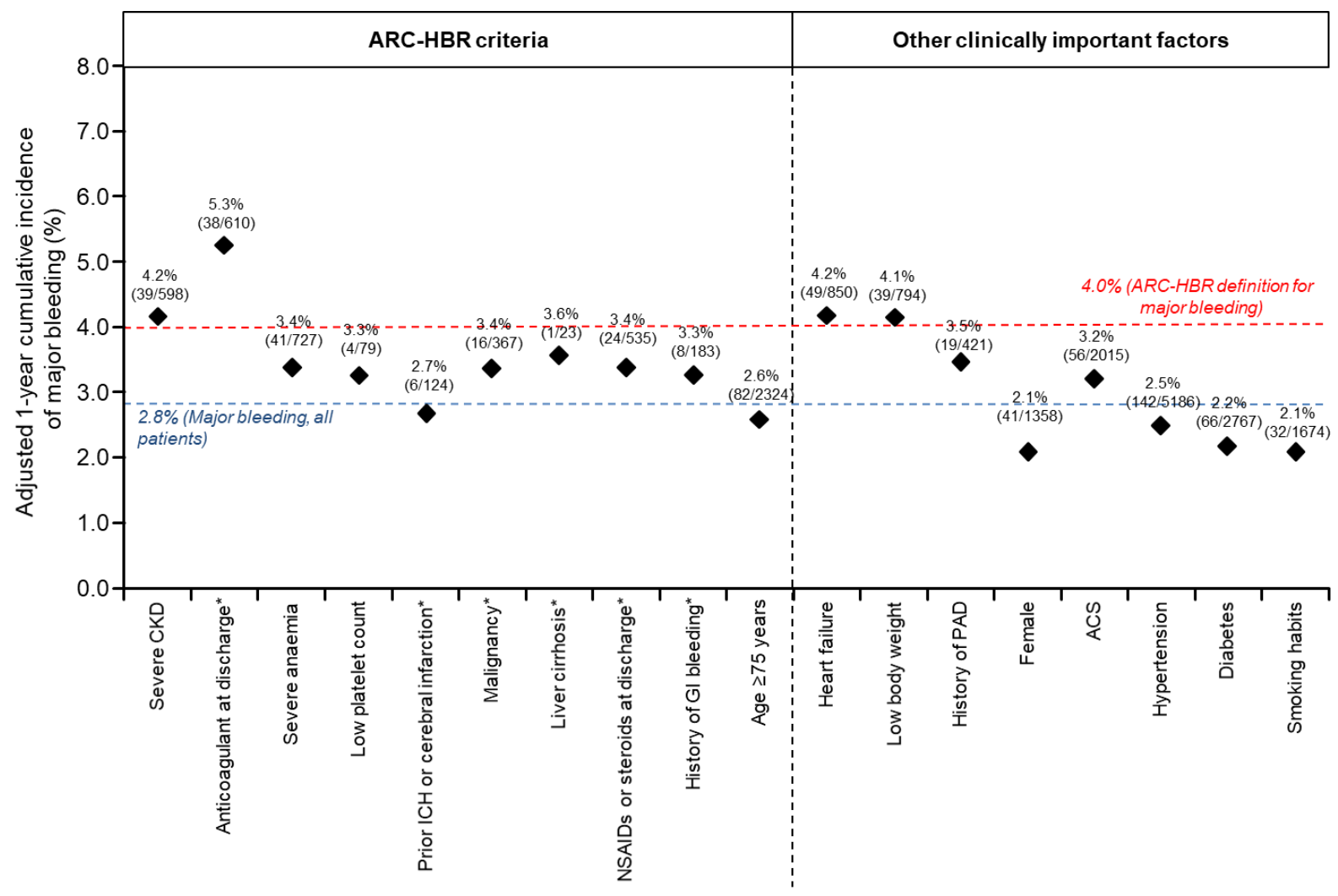

Supplementary Figure 4. Adjusted cumulative incidence of major bleeding stratified by ARC-HBR criteria and other clinically important factors.

*Modified from the original ARC-HBR criteria.

ACS: acute coronary syndrome; ARC: Academic Research Consortium; CKD: chronic kidney disease; GI: gastrointestinal; HBR: high bleeding risk; ICH: intracranial haemorrhage; PAD: peripheral arterial disease 
5A)
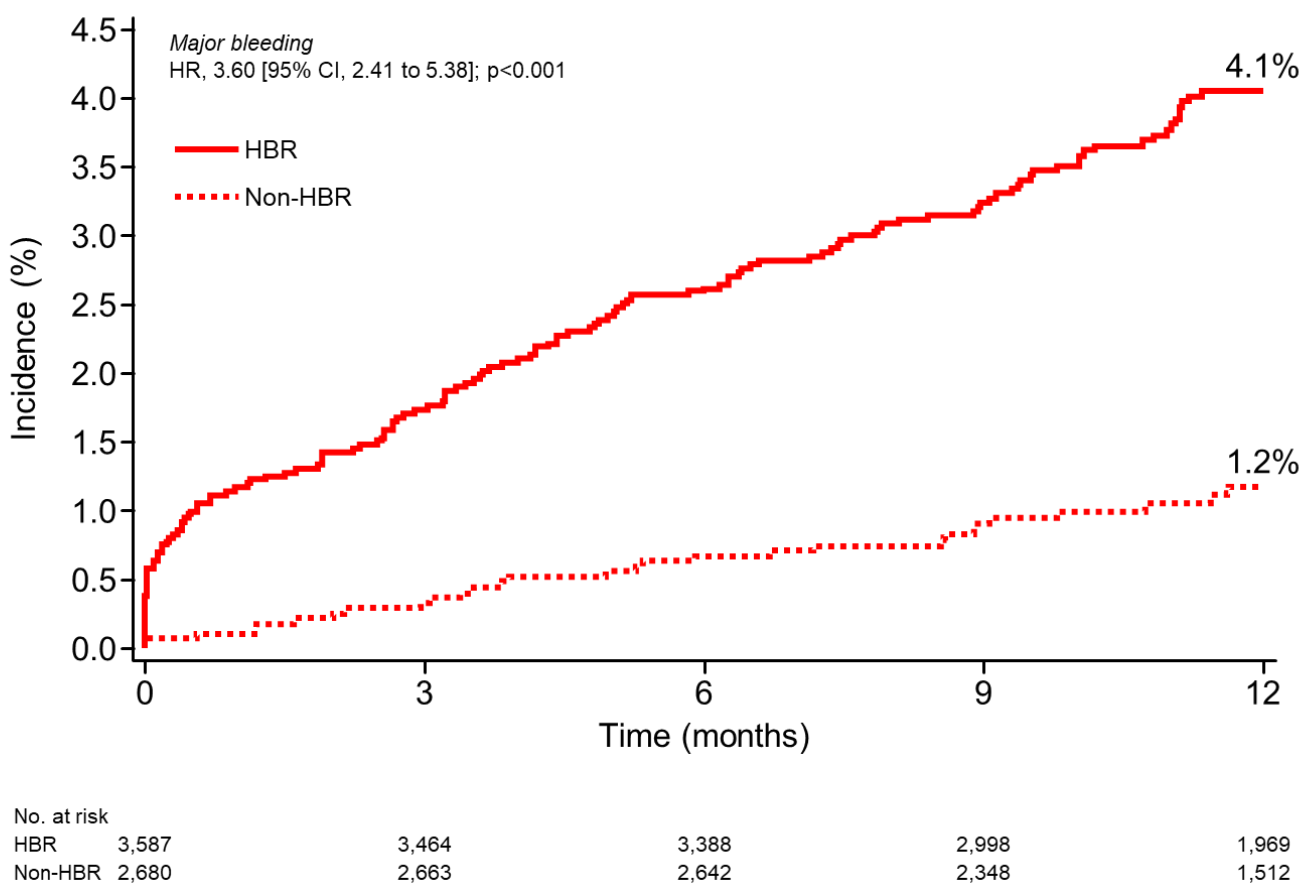

5B)

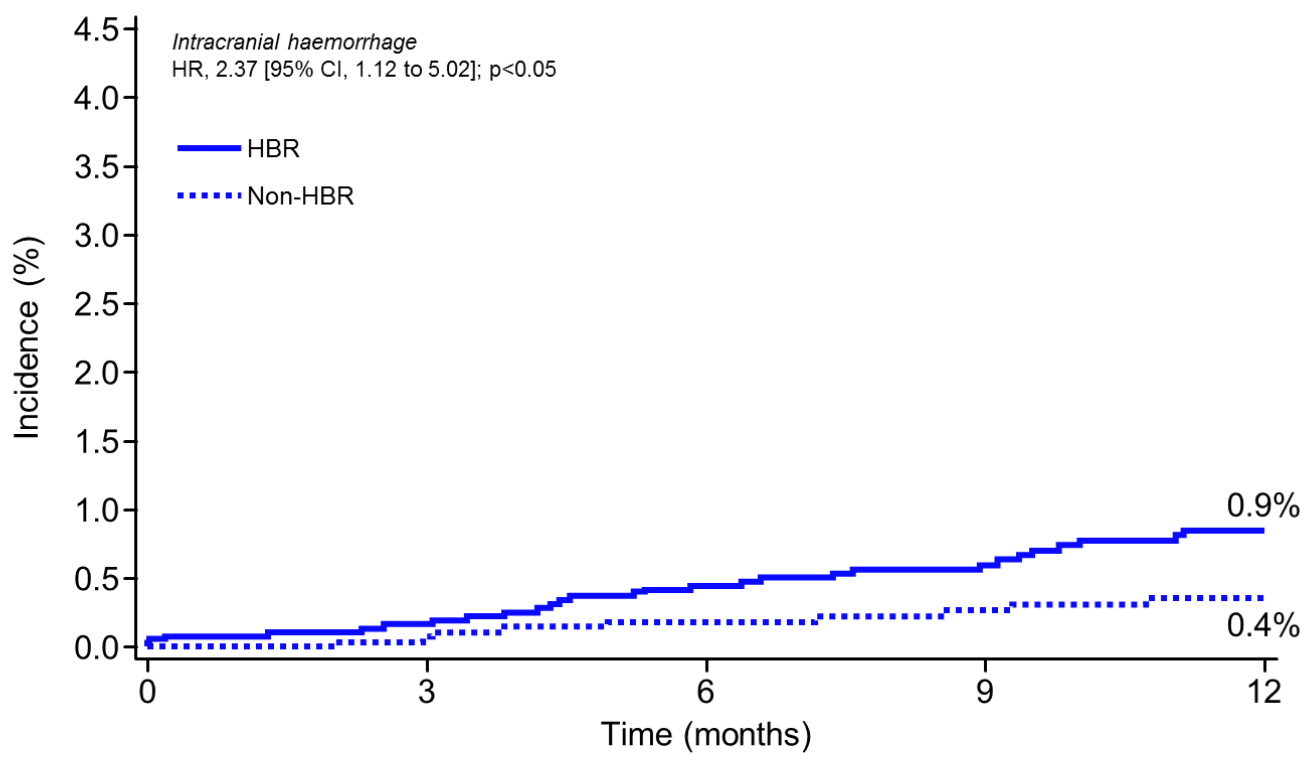

$\begin{array}{llllll}\text { No. at risk } & & & & \\ \text { HBR } & 3,587 & 3,514 & 3,455 & 3,073 & 2,026 \\ \text { Non-HBR } & 2,680 & 2,670 & 2,655 & 2,362 & 1,523\end{array}$

Supplementary Figure 5. Cumulative incidence of major bleeding (A) and intracranial haemorrhage (B) by ARC-HBR criteria plus low body weight and heart failure.

ARC: Academic Research Consortium; CI: confidence interval; HBR: high bleeding risk; HR: hazard ratio 
6A)

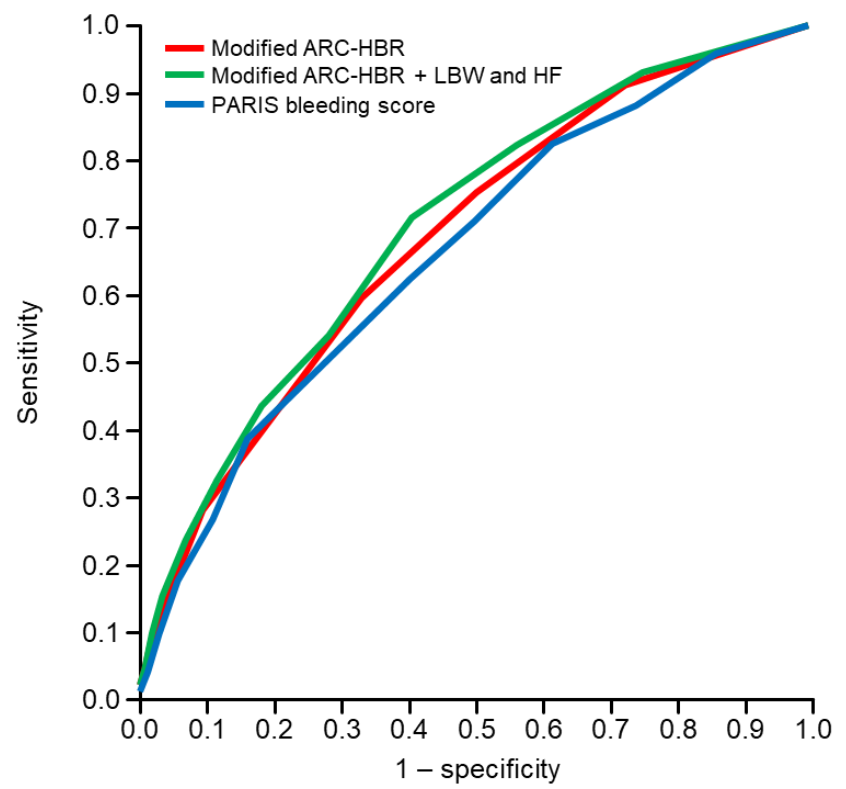

\begin{tabular}{|c|c|c|c|c|}
\hline Risk score $(\mathrm{N}=6,267)$ & \multicolumn{2}{|c|}{ C-index $(95 \% \mathrm{Cl})$} & Cut-off & \\
\hline Modified ARC-HBR & \multicolumn{2}{|c|}{$0.681(0.641-0.722)$} & 1.5 & \\
\hline Modified ARC-HBR + LBW and HF & \multicolumn{2}{|c|}{$0.700(0.660-0.740)$} & 1.5 & \\
\hline PARIS major bleeding score & \multicolumn{2}{|c|}{$0.662(0.620-0.704)$} & 9 & \\
\hline Criteria & HBR, n & Non-HBR, n & Sensitivity, \% & Specificity, \% \\
\hline Modified ARC-HBR $(\geq 1)$ & 3,185 & 3,082 & 75.2 & 49.8 \\
\hline Modified ARC-HBR + LBW and HF $(\geq 1)$ & 3,587 & 2,680 & 82.4 & 43.4 \\
\hline PARIS major bleeding score $(\geq 8)$ & 1,692 & 4,575 & 48.5 & 73.6 \\
\hline
\end{tabular}


6B)

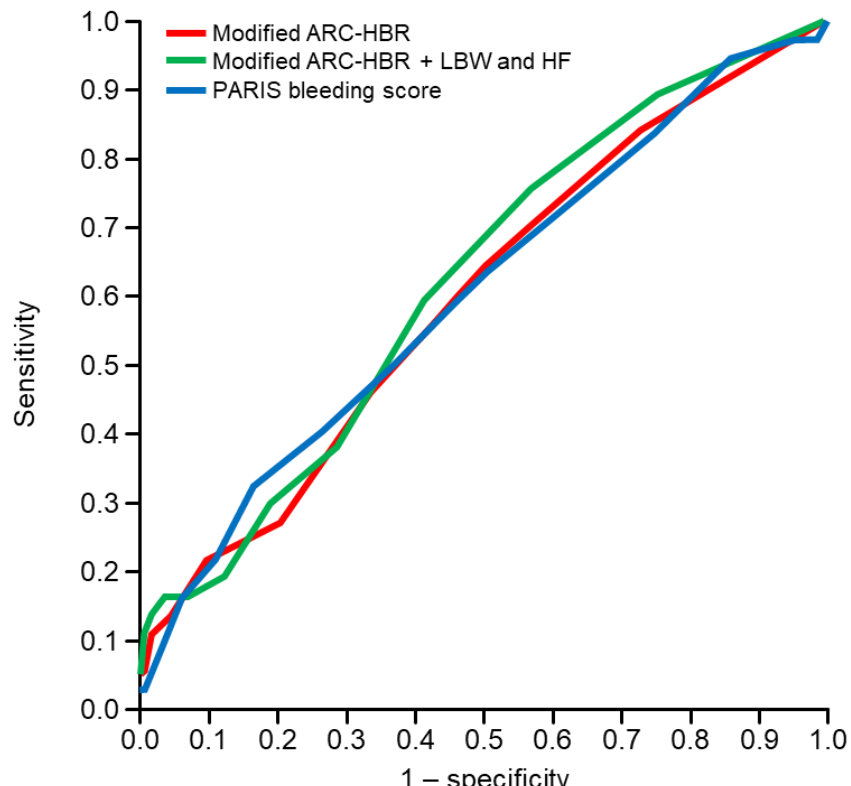

\begin{tabular}{|l|c|c|}
\hline Risk score (N=6,267) & C-index $\mathbf{( 9 5 \% ~ C l )}$ & Cut-off \\
\hline Modified ARC-HBR & $0.597(0.505-0.689)$ & 1.0 \\
\hline Modified ARC-HBR + LBW and HF & $0.620(0.533-0.708)$ & 1.0 \\
\hline PARIS major bleeding score & $0.602(0.508-0.697)$ & 9 \\
\hline
\end{tabular}

\begin{tabular}{|l|c|c|c|c|}
\hline Criteria & HBR, $\mathbf{n}$ & Non-HBR, $\mathbf{n}$ & Sensitivity, \% & Specificity, \% \\
\hline Modified ARC-HBR $(\geq 1)$ & 3,185 & 3,082 & 64.9 & 49.3 \\
\hline Modified ARC-HBR + LBW and HF $(\geq 1)$ & 3,587 & 2,680 & 75.7 & 42.9 \\
\hline PARIS major bleeding score $(\geq 8)$ & 1,692 & 4,575 & 40.5 & 73.1 \\
\hline
\end{tabular}

Supplementary Figure 6. Receiver operating characteristic curve analysis of major bleeding (A) and intracranial haemorrhage (B) for each bleeding risk criterion category.

ARC: Academic Research Consortium; CI: confidence interval; HBR: high bleeding risk; HF: heart failure; LBW: low body weight 


\section{Supplementary Table 1. Full methodological details of the PENDULUM (Platelet rEactivity in patieNts with DrUg eLUting stent and balancing risk of bleeding and ischeMic event) registry study $^{7}$.}

\begin{tabular}{|c|c|}
\hline Item & Details \\
\hline Study design & A prospective, multicentre study of Japanese patients who underwent PCI \\
\hline $\begin{array}{l}\text { Enrolment } \\
\text { period }\end{array}$ & Between December 2015 and June 2017 \\
\hline Setting & $\begin{array}{l}67 \text { Japanese institutions, nationwide. Patients were followed up as part of routine } \\
\text { clinical practice. Patients were expected to visit the hospital whenever possible, but } \\
\text { could be questioned by telephone or letter if visits were difficult. }\end{array}$ \\
\hline $\begin{array}{l}\text { Inclusion } \\
\text { criteria }\end{array}$ & $\begin{array}{l}\text { Age } \geq 20 \text { years } \\
\text { Indicated for PCI with drug-eluting stents } \\
\text { Administered antiplatelet drugs }\end{array}$ \\
\hline $\begin{array}{l}\text { Exclusion } \\
\text { criteria }\end{array}$ & $\begin{array}{l}\text { Enrolment, or planned enrolment, in another clinical study before completion of the } \\
\text { observation period }\end{array}$ \\
\hline DAPT details & $\begin{array}{l}\text { DAPT was based on the standard of care; drug type, dosage, and treatment duration } \\
\text { were selected at the discretion of the attending physician } \\
\text { The standard duration of DAPT according to Japanese treatment guidelines is a } \\
\text { minimum of } 6 \text { months for non-ACS patients and a minimum of } 12 \text { months for } \\
\text { patients with ACS }\end{array}$ \\
\hline $\begin{array}{l}\text { Approved } \\
\text { dosages }\end{array}$ & $\begin{array}{l}\text { Aspirin, } 100 \mathrm{mg} \text { administered once daily; the dosage can be increased up to } 300 \mathrm{mg} \\
\text { once daily } \\
\text { Clopidogrel, } 300 \mathrm{mg} \text { administered once as a loading dose on the treatment start day, } \\
\text { followed by } 75 \mathrm{mg} \text { once daily as a maintenance dosage } \\
\text { Prasugrel, } 20 \mathrm{mg} \text { administered once as a loading dose, followed by } 3.75 \mathrm{mg} \text { once } \\
\text { daily as a maintenance dosage }\end{array}$ \\
\hline $\begin{array}{l}\text { Primary } \\
\text { endpoints }\end{array}$ & $\begin{array}{l}\text { The incidence of first MACCE event }{ }^{\mathrm{a}} \text { and first major bleeding event }{ }^{\mathrm{b}} 12 \text { months after } \\
\text { index PCI } \\
\text { Thrombotic and haemorrhagic events were evaluated by independent assessment } \\
\text { committees }\end{array}$ \\
\hline Sample size & $\begin{array}{l}\text { The required sample size for the registry was calculated based on both the incidence } \\
\text { of MACCE and major bleeding at } 12 \text { months after index PCI } \\
\text { Published data suggested that in the Japanese population the incidence of MACCE } \\
\text { was } 3 \% \text { and the incidence of major bleeding was } 4 \% \\
\text { Using this information, the incidence of the primary endpoints was set at } 3 \% \text { with a } \\
\text { precision of } \pm 0.5 \% \text { within the range of the } 95 \% \text { CI } \\
\text { Allowing for a withdrawal rate of } 10 \% \text { during the first } 12 \text { months of the study, the } \\
\text { required number of patients was calculated as } 4,969 \text { (rounded up to } 5,000 \text { patients) }\end{array}$ \\
\hline
\end{tabular}

${ }^{a}$ Defined as all-cause death, non-fatal myocardial infarction, non-fatal stroke, and stent thrombosis.

${ }^{\mathrm{b}}$ Defined as Bleeding Academic Research Consortium types 3 and 5. 
ACS: acute coronary syndrome; CI: confidence interval; DAPT: dual antiplatelet therapy; MACCE: major adverse cardiac and cerebrovascular events; PCI: percutaneous coronary intervention 
Supplementary Table 2. High bleeding risk definitions ${ }^{\mathrm{a}}$.

\begin{tabular}{|c|c|c|c|}
\hline ARC-HBR criteria ${ }^{1}$ & This study & Category & Comments \\
\hline Age $\geq 75$ years & Age $\geq 75$ years & Minor & Identical \\
\hline $\begin{array}{l}\text { Anticipated use of long-term oral } \\
\text { anticoagulation }^{\mathrm{b}}\end{array}$ & $\begin{array}{l}\text { Use of oral anticoagulation at } \\
\text { discharge }\end{array}$ & Major & Modified \\
\hline $\begin{array}{l}\text { Severe or end-stage chronic kidney } \\
\text { disease (eGFR }<30 \mathrm{~mL} / \mathrm{min})\end{array}$ & $\mathrm{eGFR}<30 \mathrm{~mL} / \mathrm{min} / 1.73 \mathrm{~m}^{2}$ & Major & Identical \\
\hline $\begin{array}{l}\text { Moderate chronic kidney disease } \\
\text { (eGFR } 30-59 \mathrm{~mL} / \mathrm{min} \text { ) }\end{array}$ & eGFR $30-<60 \mathrm{~mL} / \mathrm{min} / 1.73 \mathrm{~m}^{2}$ & Minor & Identical \\
\hline Haemoglobin $<11 \mathrm{~g} / \mathrm{dL}$ & Haemoglobin $<11 \mathrm{~g} / \mathrm{dL}$ & Major & Identical \\
\hline $\begin{array}{l}\text { Haemoglobin } 11-12.9 \mathrm{~g} / \mathrm{dL} \text { for men } \\
\text { and } 11-11.9 \mathrm{~g} / \mathrm{dL} \text { for women }\end{array}$ & $\begin{array}{l}\text { Haemoglobin } 11-<13 \mathrm{~g} / \mathrm{dL} \text { for } \\
\text { men and } 11-<12 \mathrm{~g} / \mathrm{dL} \text { for } \\
\text { women }\end{array}$ & Minor & Identical \\
\hline $\begin{array}{l}\text { Spontaneous bleeding requiring } \\
\text { hospitalisation or transfusion in the past } \\
6 \text { months or at any time, if recurrent }\end{array}$ & & Major & $\begin{array}{l}\text { Not } \\
\text { applicable }\end{array}$ \\
\hline $\begin{array}{l}\text { Spontaneous bleeding requiring } \\
\text { hospitalisation or transfusion within the } \\
\text { past } 12 \text { months not meeting the major } \\
\text { criterion }\end{array}$ & $\begin{array}{l}\text { Prior gastrointestinal bleeding } \\
\text { at any time }\end{array}$ & Minor & Modified \\
\hline $\begin{array}{l}\text { Moderate or severe baseline } \\
\text { thrombocytopaenia }^{\mathrm{c}} \text { (platelet count } \\
\left.<100 \times 10^{9} / \mathrm{L}\right)\end{array}$ & Platelet count $<100 \times 10^{9} / \mathrm{L}$ & Major & Identical \\
\hline Chronic bleeding diathesis & & Major & $\begin{array}{l}\text { Not } \\
\text { applicable }\end{array}$ \\
\hline Liver cirrhosis with portal hypertension & Liver cirrhosis & Major & Modified \\
\hline $\begin{array}{l}\text { Long-term use of oral NSAIDs or } \\
\text { steroids }\end{array}$ & $\begin{array}{l}\text { Use of NSAIDs or steroids at } \\
\text { discharge }\end{array}$ & Minor & Modified \\
\hline $\begin{array}{l}\text { Active malignancy }{ }^{\mathrm{d}} \text { (excluding non- } \\
\text { melanoma skin cancer) within the past } \\
12 \text { months }\end{array}$ & $\begin{array}{l}\text { Malignancy at baseline } \\
\text { (undergoing or planning } \\
\text { treatment) }\end{array}$ & Major & Modified \\
\hline
\end{tabular}




\begin{tabular}{|l|l|l|l|}
\hline $\begin{array}{l}\text { Previous spontaneous intracranial } \\
\text { haemorrhage (at any time) } \\
\text { Previous traumatic intracranial } \\
\text { haemorrhage within the past } 12 \text { months } \\
\text { Presence of a brain arteriovenous } \\
\text { malformation } \\
\text { Moderate or severe ischaemic stroke } \\
\text { within the past } 6 \text { months }\end{array}$ & $\begin{array}{l}\text { History of intracranial } \\
\text { haemorrhage at any time }\end{array}$ & Major & \\
\hline $\begin{array}{l}\text { Any ischaemic stroke at any time not } \\
\text { meeting the major criterion }\end{array}$ & History of ischaemic stroke & Minor & Identical \\
without intracranial & haemorrhage at any time & & \\
\hline $\begin{array}{l}\text { Non-deferrable major surgery on dual } \\
\text { antiplatelet therapy }\end{array}$ & & Major \\
\hline $\begin{array}{l}\text { Recent major surgery or major trauma } \\
\text { within } 30 \text { days before PCI }\end{array}$ & & $\begin{array}{l}\text { Not } \\
\text { applicable }\end{array}$ \\
\hline
\end{tabular}

aDefinition of ARC-HBR: meets at least one of the major criteria or at least two of the minor criteria. The major and minor criteria were defined differently for the original article and the current analysis, as shown.

${ }^{\mathrm{b}}$ This excludes vascular protection doses.

${ }^{\mathrm{c}}$ Baseline thrombocytopaenia is defined as thrombocytopaenia before PCI.

${ }^{\mathrm{d}}$ Active malignancy is defined as diagnosis within 12 months and/or ongoing requirement for treatment (including surgery, chemotherapy, or radiotherapy).

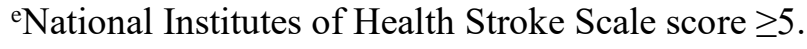

fFor the present analysis, "Spontaneous bleeding requiring hospitalisation or transfusion within the past 12 months not meeting the major criterion" was combined with "Spontaneous bleeding requiring hospitalisation or transfusion in the past 6 months or at any time, if recurrent", to form the major criterion "Composite of prior bleeding".

${ }^{\text {g} F o r ~ t h e ~ p r e s e n t ~ a n a l y s i s, ~ " A n y ~ i s c h a e m i c ~ s t r o k e ~ a t ~ a n y ~ t i m e ~ n o t ~ m e e t i n g ~ t h e ~ m a j o r ~ c r i t e r i o n " ~ w a s ~}$ combined with "Moderate or severe ischaemic stroke within the past 6 months", to form the major criterion "History of ischaemic stroke".

ARC: Academic Research Consortium; eGFR: estimated glomerular filtration rate; HBR: high bleeding risk; NSAIDs: non-steroidal anti-inflammatory drugs; PCI: percutaneous coronary intervention 
Supplementary Table 3. Baseline laboratory parameters.

\begin{tabular}{|c|c|c|c|c|}
\hline Characteristics & $\begin{array}{c}\text { Total } \\
(\mathrm{N}=6,267)\end{array}$ & $\begin{array}{l}\text { ARC-HBR } \\
(\mathbf{n}=\mathbf{3 , 1 8 5})\end{array}$ & $\begin{array}{c}\text { Non-ARC- } \\
\text { HBR } \\
(n=3,082)\end{array}$ & $\begin{array}{c}p \text {-value } \\
\text { (ARC-HBR vs } \\
\text { non-ARC- } \\
\text { HBR) }\end{array}$ \\
\hline Haemoglobin, g/dL & $\mathrm{N}=6,087$ & $\mathrm{~N}=3,108$ & $\mathrm{~N}=2,979$ & \\
\hline Mean (SD) & $13.3(2.0)$ & $12.3(1.9)$ & $14.4(1.6)$ & $<0.001$ \\
\hline$<11$ & $727(11.6)$ & $727(22.8)$ & $0(0.0)$ & $<0.001$ \\
\hline $\begin{array}{l}\text { Male: } \geq 11 \text { to }<13 ; \\
\text { Female: } \geq 11 \text { to }<12\end{array}$ & $1,414(22.6)$ & $1,204(37.8)$ & $210(6.8)$ & $<0.001$ \\
\hline $\mathrm{eGFR}, \mathrm{mL} / \mathrm{min} / 1.73 \mathrm{~m}^{2}$ & $\mathrm{~N}=6,122$ & $\mathrm{~N}=3,133$ & $\mathrm{~N}=2,989$ & \\
\hline Mean (SD) & $61.2(27.6)$ & $49.6(23.5)$ & $73.4(26.3)$ & $<0.001$ \\
\hline$<30$ & $598(9.5)$ & $598(18.8)$ & $0(0.0)$ & $<0.001$ \\
\hline$\geq 30$ to $<60$ & $2,093(33.4)$ & $1,577(49.5)$ & $516(16.7)$ & \\
\hline $\begin{array}{l}\text { White blood cell count, } \\
\times 10^{3} / \mu \mathrm{L}\end{array}$ & $\mathrm{N}=6,086$ & $\mathrm{~N}=3,108$ & $\mathrm{~N}=2,978$ & \\
\hline Mean (SD) & $6.94(2.82)$ & $6.70(2.51)$ & $7.19(3.09)$ & $<0.001$ \\
\hline Platelet count, $\times 10^{4} / \mu \mathrm{L}$ & $\mathrm{N}=6,084$ & $\mathrm{~N}=3,107$ & $\mathrm{~N}=2,977$ & \\
\hline Mean (SD) & $21.4(6.6)$ & $20.6(6.9)$ & $22.1(6.3)$ & $<0.001$ \\
\hline$<10$ & $79(1.3)$ & $79(2.5)$ & $0(0.0)$ & $<0.001$ \\
\hline \multicolumn{5}{|l|}{ No. of diseased vessels } \\
\hline 1 & $165(50.5)$ & $1,476(46.3)$ & $1,689(54.8)$ & $<0.001$ \\
\hline (1) & $1,865(29.8)$ & 987 (31.0) & $878(28.5)$ & $<0.05$ \\
\hline 3 & $1,151(18.4)$ & $680(21.4)$ & $471(15.3)$ & $<0.001$ \\
\hline $\begin{array}{l}\text { Left main coronary } \\
\text { trunk }\end{array}$ & $349(5.6)$ & $202(6.3)$ & $147(4.8)$ & $<0.05$ \\
\hline \multicolumn{5}{|l|}{ Procedural data } \\
\hline \multicolumn{5}{|l|}{ Puncture site } \\
\hline Femoral & $1,632(26.0)$ & $986(31.0)$ & $646(21.0)$ & $<0.001$ \\
\hline Brachial & $270(4.3)$ & $177(5.6)$ & $93(3.0)$ & $<0.001$ \\
\hline Radial & $4,516(72.1)$ & $2,082(65.4)$ & $2,434(79.0)$ & $<0.001$ \\
\hline ed & & & & \\
\hline
\end{tabular}




\begin{tabular}{|c|c|c|c|c|}
\hline IVUS or OCT/OFDI & $5,918(94.4)$ & $2,999(94.2)$ & $2,919(94.7)$ & 0.342 \\
\hline \multicolumn{5}{|l|}{ Complex PCI } \\
\hline All & $1,712(27.3)$ & $676(21.2)$ & 604 (19.6) & 0.110 \\
\hline$\geq 3$ stents & $435(6.9)$ & $247(7.8)$ & $188(6.1)$ & $<0.05$ \\
\hline $\begin{array}{l}\text { Number of treatment } \\
\text { lesions } \geq 3\end{array}$ & $577(9.2)$ & $311(9.8)$ & $266(8.6)$ & 0.121 \\
\hline $\begin{array}{l}\text { Bifurcation with } 2 \\
\text { stents }\end{array}$ & $112(1.8)$ & $49(1.5)$ & $63(2.0)$ & 0.131 \\
\hline $\begin{array}{l}\text { Total stent length }>60 \\
\mathrm{~mm}\end{array}$ & 725 (11.6) & $401(12.6)$ & $324(10.5)$ & $<0.05$ \\
\hline $\begin{array}{l}\text { Chronic total occlusion } \\
\text { lesion }\end{array}$ & $429(6.8)$ & $202(6.3)$ & $227(7.4)$ & 0.109 \\
\hline
\end{tabular}

Data are presented as n (\%) or mean (SD).

ARC: Academic Research Consortium; eGFR: estimated glomerular filtration rate; HBR: high bleeding risk; IVUS: intravascular ultrasound; OCT: optical coherence tomography; OFDI: optical frequency domain imaging; PCI: percutaneous coronary intervention; SD: standard deviation 
Supplementary Table 4. The proportion of events in each combination of criteria.

\begin{tabular}{|c|c|c|c|}
\hline \multirow[t]{2}{*}{ Criteria } & \multirow{2}{*}{$\begin{array}{l}\text { Patients with } \\
\text { criteria }\end{array}$} & \multicolumn{2}{|c|}{ Events } \\
\hline & & Major bleeding & ICH \\
\hline Total & 6,267 & $165(2.6)$ & $37(0.6)$ \\
\hline \multicolumn{4}{|l|}{1 minor criterion (point: 0.5 ) } \\
\hline History of GI bleeding & 22 & $0(0.0)$ & $0(0.0)$ \\
\hline Moderate anaemia & 210 & $4(1.9)$ & $0(0.0)$ \\
\hline Moderate CKD & 516 & $8(1.6)$ & $1(0.2)$ \\
\hline NSAIDs or steroids & 120 & $2(1.7)$ & $1(0.8)$ \\
\hline$\geq 75$ years & 400 & $12(3.0)$ & $5(1.3)$ \\
\hline History of ischaemic stroke without ICH & 98 & $0(0.0)$ & $0(0.0)$ \\
\hline \multicolumn{4}{|l|}{1 major criterion (point: 1 ) } \\
\hline Severe anaemia & 35 & $2(5.7)$ & $1(2.9)$ \\
\hline Low platelet count & 6 & $0(0.0)$ & $0(0.0)$ \\
\hline Severe CKD & 40 & $0(0.0)$ & $0(0.0)$ \\
\hline OAC use & 94 & $7(7.4)$ & $1(1.1)$ \\
\hline Liver cirrhosis & 4 & $0(0.0)$ & $0(0.0)$ \\
\hline Malignancy & 38 & $1(2.6)$ & $0(0.0)$ \\
\hline History of ICH & 27 & $0(0.0)$ & $0(0.0)$ \\
\hline \multicolumn{4}{|l|}{ Combination of 2 minor criteria (point: 1 ) } \\
\hline History of GI bleeding + moderate anaemia & 5 & $0(0.0)$ & $0(0.0)$ \\
\hline History of GI bleeding + moderate CKD & 10 & $1(10.0)$ & $0(0.0)$ \\
\hline History of GI bleeding + NSAIDs or steroids & 2 & $0(0.0)$ & $0(0.0)$ \\
\hline History of GI bleeding $+\geq 75$ years & 8 & $0(0.0)$ & $0(0.0)$ \\
\hline $\begin{array}{l}\text { History of GI bleeding + history of ischaemic } \\
\text { stroke without ICH }\end{array}$ & 1 & $0(0.0)$ & $0(0.0)$ \\
\hline Moderate anaemia + moderate CKD & 130 & $6(4.6)$ & $2(1.5)$ \\
\hline Moderate anaemia + NSAIDs or steroids & 16 & $1(6.3)$ & $0(0.0)$ \\
\hline Moderate anaemia $+\geq 75$ years & 159 & $2(1.3)$ & $0(0.0)$ \\
\hline $\begin{array}{l}\text { Moderate anaemia }+ \text { history of ischaemic } \\
\text { stroke without ICH }\end{array}$ & 22 & $0(0.0)$ & $0(0.0)$ \\
\hline Moderate CKD + NSAIDs or steroids & 35 & $2(5.7)$ & $1(2.9)$ \\
\hline Moderate $\mathrm{CKD}+\geq 75$ years & 304 & $2(0.7)$ & $2(0.7)$ \\
\hline $\begin{array}{l}\text { Moderate CKD + history of ischaemic stroke } \\
\text { without ICH }\end{array}$ & 38 & $1(2.6)$ & $0(0.0)$ \\
\hline NSAIDs or steroids $+\geq 75$ years & 38 & $0(0.0)$ & $0(0.0)$ \\
\hline
\end{tabular}




\begin{tabular}{|c|c|c|c|}
\hline $\begin{array}{l}\text { NSAIDs or steroids + history of ischaemic } \\
\text { stroke without ICH }\end{array}$ & 8 & $1(12.5)$ & $0(0.0)$ \\
\hline $\begin{array}{l}\geq 75 \text { years }+ \text { history of ischaemic stroke } \\
\text { without } \mathrm{ICH}\end{array}$ & 51 & $0(0.0)$ & $0(0.0)$ \\
\hline \multicolumn{4}{|l|}{ Combination of 3 minor criteria (point: 1.5 ) } \\
\hline $\begin{array}{l}\text { History of GI bleeding + moderate anaemia }+ \\
\text { moderate CKD }\end{array}$ & 9 & $0(0.0)$ & $0(0.0)$ \\
\hline $\begin{array}{l}\text { History of GI bleeding + moderate anaemia + } \\
\text { NSAIDs or steroids }\end{array}$ & 2 & $0(0.0)$ & $0(0.0)$ \\
\hline $\begin{array}{l}\text { History of GI bleeding }+ \text { moderate anaemia }+ \\
\geq 75 \text { years }\end{array}$ & 9 & $1(11.1)$ & $0(0.0)$ \\
\hline $\begin{array}{l}\text { History of GI bleeding }+ \text { moderate anaemia }+ \\
\text { history of ischaemic stroke without ICH }\end{array}$ & 0 & - & - \\
\hline $\begin{array}{l}\text { History of GI bleeding + moderate CKD + } \\
\text { NSAIDs or steroids }\end{array}$ & 0 & & - \\
\hline $\begin{array}{l}\text { History of GI bleeding + moderate CKD }+\geq 75 \\
\text { years }\end{array}$ & 2 & $0(0.0)$ & $0(0.0)$ \\
\hline $\begin{array}{l}\text { History of GI bleeding + moderate CKD + } \\
\text { history of ischaemic stroke without ICH }\end{array}$ & 0 & - & - \\
\hline $\begin{array}{l}\text { History of GI bleeding }+ \text { NSAIDs or steroids }+ \\
\geq 75 \text { years }\end{array}$ & 2 & $0(0.0)$ & $0(0.0)$ \\
\hline $\begin{array}{l}\text { History of GI bleeding + NSAIDs or steroids + } \\
\text { history of ischaemic stroke without ICH }\end{array}$ & 0 & - & - \\
\hline $\begin{array}{l}\text { History of GI bleeding }+\geq 75 \text { years }+ \text { history } \\
\text { of ischaemic stroke without ICH }\end{array}$ & 2 & $0(0.0)$ & $0(0.0)$ \\
\hline $\begin{array}{l}\text { Moderate anaemia + moderate CKD + } \\
\text { NSAIDs or steroids }\end{array}$ & 17 & $2(11.8)$ & $0(0.0)$ \\
\hline $\begin{array}{l}\text { Moderate anaemia }+ \text { moderate } \mathrm{CKD}+\geq 75 \\
\text { years }\end{array}$ & 193 & 7 (3.6) & $2(1.0)$ \\
\hline $\begin{array}{l}\text { Moderate anaemia + moderate CKD + history } \\
\text { of ischaemic stroke without ICH }\end{array}$ & 22 & $0(0.0)$ & $0(0.0)$ \\
\hline $\begin{array}{l}\text { Moderate anaemia }+ \text { NSAIDs or steroids }+ \\
\geq 75 \text { years }\end{array}$ & 14 & $1(7.1)$ & $1(7.1)$ \\
\hline $\begin{array}{l}\text { Moderate anaemia + NSAIDs or steroids + } \\
\text { history of ischaemic stroke without ICH }\end{array}$ & 1 & $0(0.0)$ & $0(0.0)$ \\
\hline $\begin{array}{l}\text { Moderate anaemia }+\geq 75 \text { years }+ \text { history of } \\
\text { ischaemic stroke without } \mathrm{ICH}\end{array}$ & 21 & $0(0.0)$ & $0(0.0)$ \\
\hline $\begin{array}{l}\text { Moderate CKD + NSAIDs or steroids }+\geq 75 \\
\text { years }\end{array}$ & 30 & $1(3.3)$ & $0(0.0)$ \\
\hline $\begin{array}{l}\text { Moderate CKD + NSAIDs or steroids + } \\
\text { history of ischaemic stroke without ICH }\end{array}$ & 1 & $0(0.0)$ & $0(0.0)$ \\
\hline
\end{tabular}




\begin{tabular}{|c|c|c|c|}
\hline $\begin{array}{l}\text { Moderate CKD }+\geq 75 \text { years }+ \text { history of } \\
\text { ischaemic stroke without ICH }\end{array}$ & 33 & $0(0.0)$ & $0(0.0)$ \\
\hline $\begin{array}{l}\text { NSAIDs or steroids }+\geq 75 \text { years }+ \text { history of } \\
\text { ischaemic stroke without ICH }\end{array}$ & 4 & $0(0.0)$ & $0(0.0)$ \\
\hline \multicolumn{4}{|c|}{ Combination of 1 major and 1 minor criteria (point: 1.5) } \\
\hline Severe anaemia + history of GI bleeding & 5 & $0(0.0)$ & $0(0.0)$ \\
\hline Severe anaemia + moderate anaemia & 0 & - & - \\
\hline Severe anaemia + moderate CKD & 37 & $1(2.7)$ & $0(0.0)$ \\
\hline Severe anaemia + NSAIDs or steroids & 10 & $0(0.0)$ & $0(0.0)$ \\
\hline Severe anaemia $+\geq 75$ years & 43 & $1(2.3)$ & $0(0.0)$ \\
\hline $\begin{array}{l}\text { Severe anaemia + history of ischaemic stroke } \\
\text { without } \mathrm{ICH}\end{array}$ & 2 & $0(0.0)$ & $0(0.0)$ \\
\hline Low platelet count + history of GI bleeding & 0 & - & - \\
\hline Low platelet count + moderate anaemia & 3 & $0(0.0)$ & $0(0.0)$ \\
\hline Low platelet count + moderate CKD & 3 & $0(0.0)$ & $0(0.0)$ \\
\hline Low platelet count + NSAIDs or steroids & 0 & - & - \\
\hline Low platelet count $+\geq 75$ years & 2 & $0(0.0)$ & $0(0.0)$ \\
\hline $\begin{array}{l}\text { Low platelet count }+ \text { history of ischaemic } \\
\text { stroke without ICH }\end{array}$ & 1 & $0(0.0)$ & $0(0.0)$ \\
\hline Severe CKD + history of GI bleeding & 1 & $0(0.0)$ & $0(0.0)$ \\
\hline Severe CKD + moderate anaemia & 81 & $5(6.2)$ & $3(3.7)$ \\
\hline Severe CKD + moderate CKD & 0 & - & - \\
\hline Severe CKD + NSAIDs or steroids & 9 & $0(0.0)$ & $0(0.0)$ \\
\hline Severe CKD $+\geq 75$ years & 23 & $3(13.0)$ & $0(0.0)$ \\
\hline $\begin{array}{l}\text { Severe CKD + history of ischaemic stroke } \\
\text { without ICH }\end{array}$ & 5 & $0(0.0)$ & $0(0.0)$ \\
\hline OAC use + history of GI bleeding & 3 & $0(0.0)$ & $0(0.0)$ \\
\hline OAC use + moderate anaemia & 28 & $2(7.1)$ & $0(0.0)$ \\
\hline OAC use + moderate CKD & 53 & $2(3.8)$ & $0(0.0)$ \\
\hline OAC use + NSAIDs or steroids & 8 & $0(0.0)$ & $0(0.0)$ \\
\hline OAC use $+\geq 75$ years & 39 & $2(5.1)$ & $0(0.0)$ \\
\hline $\begin{array}{l}\text { OAC use + history of ischaemic stroke without } \\
\text { ICH }\end{array}$ & 15 & $1(6.7)$ & $1(6.7)$ \\
\hline Liver cirrhosis + history of GI bleeding & 0 & - & - \\
\hline Liver cirrhosis + moderate anaemia & 1 & $0(0.0)$ & $0(0.0)$ \\
\hline Liver cirrhosis + moderate CKD & 0 & - & - \\
\hline Liver cirrhosis + NSAIDs or steroids & 0 & - & - \\
\hline Liver cirrhosis $+\geq 75$ years & 0 & - & - \\
\hline
\end{tabular}




\begin{tabular}{|c|c|c|c|}
\hline $\begin{array}{l}\text { Liver cirrhosis }+ \text { history of ischaemic stroke } \\
\text { without ICH }\end{array}$ & 0 & - & - \\
\hline Malignancy + history of GI bleeding & 1 & $0(0.0)$ & $0(0.0)$ \\
\hline Malignancy + moderate anaemia & 17 & $0(0.0)$ & $0(0.0)$ \\
\hline Malignancy + moderate CKD & 19 & $0(0.0)$ & $0(0.0)$ \\
\hline Malignancy + NSAIDs or steroids & 4 & $0(0.0)$ & $0(0.0)$ \\
\hline Malignancy $+\geq 75$ years & 35 & $0(0.0)$ & $0(0.0)$ \\
\hline $\begin{array}{l}\text { Malignancy }+ \text { history of ischaemic stroke } \\
\text { without ICH }\end{array}$ & 2 & $0(0.0)$ & $0(0.0)$ \\
\hline History of ICH + history of GI bleeding & 0 & - & - \\
\hline History of ICH + moderate anaemia & 9 & $0(0.0)$ & $0(0.0)$ \\
\hline History of ICH + moderate CKD & 8 & $0(0.0)$ & $0(0.0)$ \\
\hline History of ICH + NSAIDs or steroids & 0 & - & - \\
\hline History of $\mathrm{ICH}+\geq 75$ years & 5 & $0(0.0)$ & $0(0.0)$ \\
\hline $\begin{array}{l}\text { History of ICH + history of ischaemic stroke } \\
\text { without ICH }\end{array}$ & 0 & & - \\
\hline \multicolumn{4}{|c|}{1 major criterion (point: 1) * East Asian-specific HBR only } \\
\hline Body weight $\leq 50 \mathrm{~kg}$ & 74 & $0(0.0)$ & $0(0.0)$ \\
\hline Heart failure & 80 & $2(2.5)$ & $2(2.5)$ \\
\hline
\end{tabular}

Data are presented as $\mathrm{n}(\%)$.

CKD: chronic kidney disease; GI: gastrointestinal; HBR: high bleeding risk; ICH: intracranial haemorrhage; NSAIDs: non-steroidal anti-inflammatory drugs; OAC: oral anticoagulant 